\title{
SHORTER CONTRIBUTIONS TO GENERAL GEOLOGY, 1922.
}

\author{
ADDITIONS TO THE FLORA OF THE WILCOX GROUP.
}

By Edward Wilber Berry.

A rather full account of the extensive flora contained in the lower Eocene strata of the Mississippi embayment which are referred to the Wilcox group was published in $1916 .{ }^{1}$ At that time it was not possible to obtain sections of the numerous specimens of petrified wood that had been collected from these beds. These woods have since been sectioned and studied, and it seems eminently desirable to place the results of this study on record, for although much of the material had suffered greatly from decay before silicification, some of it is fairly well preserved and shows, among other results, that conifers were individually much more plentiful during Wilcox time than would be inferred from the almost total absence of their foliage in the very large collections of remains of this class that have been studied.

Moreover, these coniferous woods show wellmarked seasonal rings, indicating periodicity in the climate, which can be explained as due either to severity of winters or to a seasonal rainfall and a regularly recurring dry season. As the facies of the flora appears to preclude the first alternative, the second would seem established, except that the general character of the flora is equally opposed to this alternative. As both the pines and the bald cypress in the existing flora at their southern limit in peninsular Florida show annual rings, it seems to me that a somewhat similar winter season must be predicated for the Wilcox. This does not mean annual snow or frost, although freezes may have occurred at intervals of years. Severity is a relative term, and I would not expect the Wilcox climate, even at the north end of the embayment, near the

\footnotetext{
1 Berry, E. W., U. S. Geol. Survey Prof. Paper 91, 1916.
}

present mouth of the Ohio, to have been any more severe during the winter than the present climate, for example, of Fort Pierce, in the southern Indian River region of peninsular Florida. This conclusion is practically the same as that arrived at in the previous analysis of the Wilcox flora.

Very little has heretofore been known of the Wilcox flora in the Texas area. In Professional Paper 91 Wilcox plants were recorded from only three localities in Texas, and two of these-Old Port Caddo Landing, in Harrison County, and Sabine River in Sabine Countyare in the extreme eastern part of the State. The third and westernmost locality from which Wilcox plants had been recorded is on Calaveras Creek in Wilson County. That the lack of fossils from the Wilcox in the region between San Antonio and the Rio Grande was due entirely to lack of exploration was shown by a short trip through this region during 1921. Although fossil plants are not so common there as farther east, because the upper Wilcox, which alone crops out, contains a large proportion of sandy beds, long ago recognized as the Carrizo sandstone, several collections were obtained. The age of the Carrizo sandstone has heretofore been somewhat uncertain. Referred originally to the Wilcox, it has been considered to be of Claiborne age by several Texas geologists. The plants found in the Carrizo sandstone, as well as those found both above and below it near the Rio Grande, definifely settle its upper Wilcox age. These will be discussed on a subsequent page.

In addition, a few collections have been sent to me from time to time from new localities, and I am particularly indebted to Mr. O. M. Ball for a large collection obtained near Mansfield, La. 
In Professional Faper 91 I recorded 342 species of plants from the Wilcox. In Professional Paper 108-E, published in 1917, species of Zamia and Nelumbo were added. The present contribution includes additional plants, but as a number of supposed species of Ficus are now reduced to synonymy, the total additions amount to 9 , making 353 as the number of species now recognized in the Wilcox flora.

The descriptions in the present paper include both lauraceous and sterculiaceous woods, also strikingly well preserved and characteristic lauraceous fruits. Other novelties are a liverwort (Marchantites,) the fern genus Dryopteris, palm nuts, the genus Monocarpellites (which helps to prove that the lignites of Brandon, Vt., are Eocene and not Miocene), an interesting fruit of the otherwise unrepresented family Icacinaceae, and a second which is referred with some hesitation to the family Anacardiaceae.

The upper Wilcox plant-bearing bed in the Grenada formation near Grenada, Grenada County, Miss., is at the southernmost point at which determinable fossil plants had been found in the Wilcox in the eastern Gulf area. Much interest therefore attaches to a small collection made recently in southern Alabama by C. W. Cooke and J. A. Gardner. The exact locality is at the wagon bridge on Claybank Creek 1 mile west of Clayhatchee, Dale County. This is about 300 miles southeast of Grenada and east of the typical localities of marine Wilcox beds. The matrix is a sandy brown clay, and the contained leaves are poor and fragmentary. Representatives of four different species are recognizable, although but one of these is determinable, and this represents a perfect leaflet of Mimosites variabilis Berry.

The following species are recorded from the Spinks pit, near Paris, Henry County, Tenn. The specimens occur in a gray plastic clay from which the entire leaves can be washed and mounted in balsam between glass, thus forming very exceptional specimens:

\footnotetext{
Monocarpellites perkinsi Berry.

Nectandra glenni Berry.

Oreodaphne salinensis Berry.

Sapindus mississippiensis Berry.
}

The following are additions to the flora from a locality 1 mile south of Grand Junction, Tenn.:
Sabalites grayanus Lesquereux.

Oreodaphne puryearensis Berry.

At the time of publication of Professional Paper 91 the collections obtained 4 miles southwest of Boydsville, Ark., were lost, and as they had only received a preliminary study the list of species from that locality was very incomplete. These collections have since received careful study, which has shown that Ficus denveriana should be omitted from this florule and that the following species should be added:

Anacardites puryearensis Berry.

Apocynophyllum mississippiensis Berry.

Apocynophyllum wilcoxense Berry.

Cinnamomum oblongatum Berry.

Coccolobis uviferafolia Berry.

Cyperacites sp.

Engelhardtia ettingshauseni Berry.

Ficus mississippiensis (Lesquereux) Berry.

Ficus pseudocuspidata Berry.

Ficus puryearensis Berry.

Hiraea wilcoxiana Berry.

Juglans schimperi Lesquereux.

Magnolia leei Knowlton.

Myrcia vera Berry.

Nectandra puryearensis Berry.

Oreodaphne mississippiensis Berry.

Palmocarpon butlerensis Berry.

Sapindus mississippiensis Berry.

Ternstroemites eoligniticus Berry.

These all serve to emphasize the late Wilcox age of the Boydsville florule.

At a locality near Jacksonville, in Pulaski County, Ark., L. W. Stephenson collected the following species, which prove the outcrop to be of upper Wilcox age:

\author{
Celastrus taurinensis Ward. \\ Cordia? lowii Berry? \\ Dillenites microdentatus (Hollick) Berry. \\ Euonymus splendens Berry. \\ Ficus harrisiana Hollick. \\ Marchantites stephensoni Berry. \\ Nectandra cf. N. glenni Berry. \\ Nectandra sp. \\ Oreodaphne obtusifolia Berry.
}

In material from a gray plastic clay at 304 to 319 feet below the surface in a well at Negreet, 9 miles southwest of Many, Sabine Parish, La., I recognized the two following Wilcox species:

Pteris pseudopinnaeformis Lesquereux.

Simaruba eocenica Berry.

The following plants were collected by $\mathrm{O}$. M. Ball at the Goss pit, half a mile east of Mansfield, De Soto Parish, La.: 
Apocynophyllum mississippiensis Berry.

Artocarpoides balli Berry.

Bombacites formosus Berry.

Diospyros wilcoxiana Berry.

Dryopteris cladophleboides Knowlton.

Dryophyllum sp.

Euonymus splendens Berry.

Ficus artocarpoides Lesquereux.

Ficus mississippiensis (Lesquereux) Berry.

Inga laurinafolia Berry.

Juglans schimperi Lesquereux.

Laurus vera Berry.

Magnolia angustifolia Newberry.

Magnolia leei Knowlton.

Metopium wilcoxianum Rerry.

Oreodaphne salinensis Berry.

Rhamnus eoligniticus Berry.

Rhamnus marginatus Lesquereux.

Rhamnus marginatus apiculatus Berry.

Rhamnites knowltoni Berry.

Sterculia wilcoxensis Berry.

Sterculiocarpus eocenicus Berry.

Terminalia hilgardiana (Lesquereux) Berry.

Terminalia lesleyana (Lesquereux) Berry.

The following were contained in a collection from a locality 10 miles south-southwest of Palestine, Anderson County, Tex., in Post Oak Prairie, 2 miles south of Needmore (collectors, O. B. Hopkins and O. C. Funderbunk):

Canavalia eocenica Berry?

Lygodium binervatum (Lesquereux) Berry.

Nectandra pseudocoriacea Berry?

The following were sent in by the last-named collectors from the Butler (or West Point) salt dome, in the eastern part of Freestone County, near Trinity River, 6 miles northeast of Oakville, Tex.:

Mespilodaphne coushatta Berry?

Palmocarpon butlerensis Berry.

Proteoides wilcoxensis Berry.

Sophora repandifolia Berry?

Calatoloides eocenicum Berry.

The following localities in central and southwestern Texas deserve some special comment, as no collections have heretofore been made from them and they show conclusively that the Carrizo sandstone is of upper Wilcox age, but that it is in the nature of a lens which becomes thinner toward the Rio Grande, where its upper part is replaced by more typical and more argillaceous Wilcox beds that also carry characteristic fossil plants.

Fossil plants were reported by Baker from the Elmendorf clay pit, south of San Antonio, in Bexar County. This pit was not being worked in 1921 and was partly full of water, about 25 feet of grayish laminated sandy clay with local more argillaceous and darker lenses carrying leaves being all that was exposed. These leaves were poorly preserved, and the only species recognized are Ficus mississippiensis (Lesquereux) Berry, Nectandra sp., and Sapindus linearifolius Berry. The manager of the Elmendorf plant informed me that the clay formerly mined came from the flooded part of the pit and was full of impressions of leaves.

The Wilcox is well exposed along Nueces River in Zavalla County. Fossil plants were collected from the right bank 1 mile below the Pulliam ranch house. The following species are represented:

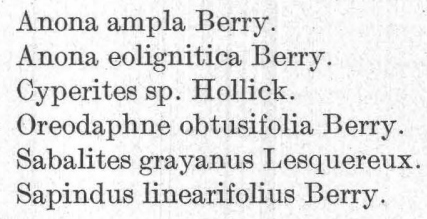

Sandy lenses contain many Sabalites, some of large size. One rachis of this species observed was $2 \frac{1}{2}$ inches in diameter at one end and 4 inches at the other. These species indicate a late Wilcox age and show the transgressive character of the beds, as the Midway appears to be absent on the Nueces, the Wilcox resting on the Cretaceous and not far above the conspicuous reef of Ostrea cortex just above the San Antonio, Uvalde \& Gulf Railroad bridge.

From Story's ranch to La Pryor crossing there is a long exposure of typical Wilcox beds, especially along the left bank of the Nueces for about 2 miles above the crossing. Fossil plants are abundant but so poorly preserved that no collections were made, although several Wilcox species were recognized.

From the crossing southward the Carrizo sandstone is exposed. At an outcrop in a deep arroyo along the left bank $1 \frac{1}{2}$ miles south of the crossing there is an exposure of about 30 feet of buff heavily bedded and prominently cross-bedded sand. At the base of this sand 3 to 4 feet of a small brownish clay lens is visible. This lens, which is stratigraphically above the ferruginous quartzite sand exposed at the crossing, is full of leaves. The following species, which indicate upper Wilcox age, were collected:

Banksia puryearensis Berry.

Eugenia grenadensis Berry. 
Gleditsiophyllum eocenicum Berry.

Mespilodaphne coushatta Berry.

Myrcia vera Berry.

Persea longipetiolatum (Hollick) Berry.

Sabalites grayanus Lesquereux.

The type exposure of the Carrizo sandstone is in the quarries about half a mile west of Carrizo Springs, in Dimmit County. This, as well as the numerous other exposures of Carrizo and other Wilcox deposits in southwestern Texas, will be described in detail in A. C. Trowbridge's report on this region.

From the Carrizo sandstone at the type locality the following species were collected:

Acrostichum sp.

Anona ampla Berry.

Anona wilcoxiana Berry.

Uanavalia eocenica Berry?

Cassia tennesseensis Berry.

Cinnamomum vera Berry?

Dryophyllum tennesseensis Berry?

Ficus mississippiensis (Lesquereux) Berry.

Nectandra pseudocoriacea Berry.

Oreodaphne obtusifolia Berry.

Oreodaphne puryearensis Berry.

Palmocarpon butlerensis Berry.

Pterobalanus texanus Berry.

Sabalites grayanus Lesquereux.

Sophora wilcoxiana Berry.

Sterculia wilcoxensis Berry.

The foregoing list represents a typical upper Wilcox flora. Fragments of leaves are not at all uncommon in the hard sandstones of the Carrizo and were observed at a considerable number of additional outcrops, but the hardness of the material rendered collecting difficult, and the coarseness of the matrix, which obliterated the venation, made the determinations inconclusive. Nowhere, however, did these fragments suggest Claiborne forms, but all were believed to represent well-known upper Wilcox species.

Near the Rio Grande the Carrizo sandstone becomes thin and is overlain by beds showing more typical Wilcox lithology. A section on Concillas Creek a quarter of a mile above its mouth, in Webb County, exposes the following materials:

\section{Sandstone.}

Brownish laminated clay with leaves.

Local unconformity.

Ripple-marked sandstone.

Clay parting.

Sandstone with sticks and leaf fragments.

Gray clay.
From the brownish clay above the local unconformity, not far below the Wilcox-Mount Selman contact, the following plants were collected:
Anacardites grevilleafolia Berry.
Banksia puryearensis Berry.
Cassia marshallensis Berry.
Cyperites sp. Hollick.
Inga wickliffensis Berry?
Juglans schimperi Lesquereux.
Mimosites variabilis Berry.
Mimusops mississippiensis Berry.
Myrica wilcoxensis Berry.
Sabalites grayanus Lesquereux.
Sophora wilcoxiana Berry.

From the sandstone two excellent specimens of Canna eocenica Berry were collected. The whole section is clearly upper Wilcox in age.

From Elm Creek on the Schuddemagen ranch, in eastern Uvalde County, considerably above the Cretaceous-Midway contact described by Stephenson, ${ }^{2}$ a single specimen of Rhamnus coushatta Berry was collected. This is a typical upper Wilcox form and suggests that the Midway is unusually thin in this section, which is in conformity with its entire absence on the Nueces.

A systematic account of the new or noteworthy species of plants that have been added to the flora of the Wilcox group and are discussed in the present contribution is given below.

\section{Phylum BRYOPHYTA.}

Class HePATICAE.

Order MARCHANTIALES.

Genus MARCHANTITES Brongniart.

Marchantites stephensoni Berry, n. sp.

Plate IV, figure 1.

Plant body thallose, consisting of a linear, repeatedly dichotomously forked thallus thickened medianly and with somewhat irregularly placed oblique and transverse markings, believed to represent appressed rhizoids.

The material is scanty and of slight botanic importance. Except that the margins are straighter the present form is indistinguishable from Marchantia sezannensis Brongniart, ${ }^{3}$ from

2 Stephenson, L. W., U. S. Geol. Survey Prof. Paper 90, p. 177, 1915.

3 Saporta, G. de, Prodrome d'une flore fossile des travertins anciens de Sézanne, p. 308, pl. 1, figs. 1-8, 1868. 
the Paleocene of France, which has the distinction of having the receptacles preserved and therefore being conclusively identified. The present form is also much like Marchantia pealei Knowlton, ${ }^{4}$ of the Fort Union formation of Montana.

Thalloid liverworts are so rarely found in the geologic record that any of them are noteworthy. Similar remains are recorded from several Jurassic and Lower Cretaceous outcrops both in this country and abroad, and several Eocene and Oligocene species have been described.

The present species is named for the collector and comes from the upper Wilcox deposits near Jacksonville, Pulaski County, Ark.

Phylum PTERIDOPHYTA.

Class LEPTOSPORANGIATAE.

Order POLYPODIALES.

Family POLYPODIACEAE

Genus DRYOPTERIS Adamson.

Dryopteris cladophleboides Knowlton.

Plate IV, figures 5-7.

Dryopteris? cladophleboides Knowlton, U. S. Geol. Survey Prof. Paper 101, p. 284, pl. 54, fig. 1, 1918.

Frond pinnate or bipinnate. Pinnae long, linear-lanceolate, divided nearly or quite to the rachis into numerous ovate-lanceolate, oblong, or conical obtuse or acutely pointed pinnules, with entire margins. Texture coriaceous. Rachis stout, channeled. Midrib of pinnules stout, diverging from the rachis at angles of about $65^{\circ}$ to $70^{\circ}$, curving slightly upward distad, its course throughout nearer to the proximal margin of the pinnule. The lateral veins are thin and closely spaced; they diverge at wide angles and number about 16 pairs. Those in the tip of the pinnule are simple; the majority are once forked; several basal pairs, particularly on the proximal side of the pinna, pass from a single lateral with two simple branches to a lateral with two dichotomous forks, as shown in the accompanying figure. There is some variation in the shape and degree of separation of the pinnules.

The specimens are five in number, and none axe especially complete. All are sterile. The pinnae were at least 10 centimeters in length,

\footnotetext{
${ }^{4}$ Knowlton, F. H., U. S. Nat. Mus. Proc., vol. 35, pp. 157-159, pl. 25,
} 1908. and the pinnules are about 1 centimeter in length by about 4 millimeters in width at their base. There is in the collection, however, a tiny specimen showing about 5 millimeters of a similar rachis with the impression of four stout pinnules. These are slightly smaller than the sterile pinnules but have the same form and confluent bases; the midribs are stout; the lateral veins are thin and fewer than in the sterile pinnules; about halfway between the midrib and the margin each lateral shows the impression of a small, approximately circular and prominent sorus, and these decrease in size distad; there are about six prominent ones in each half of the lamina. Several of the proximal laterals are seen to be forked beyond the sori, but the majority appear to be simple.

Although these fertile pinnules are not in organic union with the sterile parts of the frond, their association in a thin stratum at the same outcrop and the further fact that no similar species are known in the whole Wilcox flora make it seem very probable that both belong to the same form, and this conclusion is corroborated by their form and attitude, similar rachis, similar midrib, and lateral veins.

The type material of this species, described by Knowlton, came from the Raton formation of southeastern Colorado. It was very incomplete, with the venation obscured. There seems to be no doubt, however, that the Wilcox occurrence represents the same, species, a type of fern hitherto unknown in the Wilcox flora, in which ferns are unusually scarce.

Both the sterile and fertile pinnules are similar to those of certain species of Alsophila and Cyathea, and they are practically identical with a number of existing species of Dryopteris, as for example Dryopteris concinnum Mettenius, D. molle Swartz, and D. pteroides Swartz. I can see no reason for questioning their reference to Dryopteris.

The genus Dryopteris is a large one in the modern flora, with more than 1,000 species variously segregated or aggregated by students of existing ferns in the genera Lastrea, Nephrodium, Phegopteris, Polybotrya, and Dryopteris. Christensen ${ }^{5}$ unites them all in a single genus divided into 10 subgenera, many of which are entitled to generic rank, as I have pointed out several times in describing Tertiary species of

${ }^{5}$ Christensen, C., On a natural classification of the species of Dryopteris: Saertryk af Biologiske Arbeijdner Tilegnede E. Warming, pp. 73-85, 1911. 
Goniopteris, of which there is a very characteristic form in the Claiborne. ${ }^{6}$ The dryopterids are widely distributed and mainly tropical, although Christensen's subgenus Eudryopteris, with about 100 species, is largely confined to the North Temperate Zone.

Occurrence: Goss pit, half a mile east of Mansfield, De Soto Parish, La.; collected by O. M. Ball.

\section{Genus ACROSTICHUM Linné.}

Acrostichum sp.

This characteristic fern genus is represented in the Wilcox by a single fragment, too small for determination or description but showing the areolation of this genus. It is a strand type well represented in the Claiborne, Jackson, and Catahoula of the embayment area, and its unaccountable absence among the strand types in the Wilcox was the occasion for comment in the former discussions of this flora. The present fragment adds this interesting type to the Wilcox flora and raises the number of fern species known in this flora to eight.

Occurrence: Carrizo sandstone, half a mile west of Carrizo Springs, Dimmit County, Tex.

Phylum CONIFEROPHYTA.

Order PINALES.

\section{Family TAXODIACEAE.}

\section{Genus CUPRESSINOXYLON Goeppert.}

[Monographie der fossilen Coniferen, p. 196, 1850.]

Coniferous wood composed of tracheids and xylem parenchyma only. In the tracheid walls the pits are generally round, bordered, and isolated, in one row; if in two rows the pits stand in adjacent pairs and are not alternating or compressed. Sanio's rims often conspicuous. Normal resin canals entirely absent. Resin containing xylem parenchyma present, generally in large quantities, and scattered all through the wood.' Medullary rays uniseriate; a few may be partly biseriate. The cells of the rays all alike, generally smooth-walled, and without abietinean pitting (which is present in a few species); pits in the radial walls of the rays generally circular or oval, simple, small, and in groups of one to six, seldom more, per tracheid field.

Cupressinoxylon wilcoxense Berry, n. sp. Plates I-III.

Trunks, many of them of large size, preresenting this species are extremely common in

6 Berry, E. W., Torrey Bot. Club Bull., vol. 44, pp. 331-335, pl. 22, 1917.

7 Stopes, M. C., The Cretaceous flora: British Mus. Cat., pt.2, p. 167, 1915. the upper Wilcox sands of Louisiana. They have in general suffered much from decay before silicification, but some specimens are exceedingly well preserved. They are remarkable chiefly for the great variation in the width of the zone of spring wood and the well-marked or almost complete absence of summer wood. Thus in the sections figured the zone of spring wood ranges from 5 or 6 radial rows of tracheids to 23 or 24 rows, while the summer wood consists of 3 or 4 rows. In other specimens, notably two (Nos. 206, 211) from the vicinity of Naborton, La., the spring wood consists of 45 to 70 radial rows of tracheids of uniform size separated by two rows of summer wood in which the size of the tracheids or the cell lumen is so slightly reduced that a seasonal change is scarcely marked. These woods all come from the same horizon, and their variation can not be explained by the well-known differences in the annual rings of upland and lowland forms of the same species of conifers, for it is known that the Wilcox land surface was low, the nearest uplands at that time being in the Rocky Mountain region. It is of course possible that the present species extended its range westward through Colorado and that some of these large trunks may have been brought down from the west by river floods, for at the present time Red River reaches nearly to the New Mexico boundary, and the headwaters of Arkansas River reach the foothills of the Sangre de Cristo Mountains and the Front Range in central and southern Colorado. In general the best-preserved material shows the narrower and more marked growth rings, but both types are found in all stages of decay, so that no reliable conclusions can be drawn.

Transverse section: Growth rings feebly developed or well marked, variable in width in individual specimens. Spring wood of relatively large, thin-walled, mostly isodiametric tracheids and xylem parenchyma, the two elements not distinguishable in this section, arranged in radial rows of 5 to 70 cells, averaging 10 or 12 . Cell outlines round with wide lumen; diameter variable for different radial rows but in general uniform for each row, ranging from 0.025 to 0.975 millimeter. Summer wood consisting of two to four rows of somewhat reduced tracheids with narrower lumen or in some specimens scarcely reduced 
or narrowed and consisting of only one or two rows of cells.

Radial section: Tracheids with one or two rows of mostly well-spaced circular-bordered pits. When in single rows the pits are somewhat larger, and when in double rows the pits are almost invariably in pairs, although occasionally they may alternate for a short distance, as in the specimen figured; usually wellspaced occasional rows are in contact, as shown in the figure. The rims of Sanio are often prominently shown in the sections of the tangential walls. The septate xylem parenchyma is conspicuous in this section, the partitions being at right angles to the walls and from three to four times the diameter or slightly farther apart, usually containing more or less resin. The diameter of the xylem parenchyma is about the same as that of the tracheids but may be slightly greater. It is not excessively abundant, as in some other species of Cupressinoxylon, nor is it generally completely filled with resin. No traumatic or other resin canals are observable. Ray cells uniform in character seem to be radially elongated, with a radial length of $1 \frac{1}{2}$ to 2 tracheid fields and a height about one-fourth their length. End walls smooth (without abietinean pitting), mostly transverse and rarely much oblique; one or more in each ray partly resiniferous; radial walls with two small oval pits per tracheid field; these pits are relatively large for this genus and appear to have their long axis uniformly inclined about $40^{\circ}$ from the vertical.

Tangential section: The distribution and relative abundance and variation in the rays are well shown in the figure of a large area under low magnification (20 diameters). The rays are uniformly uniseriate, of relatively large, thin-walled, roundish quadrangular cells, one or more of which may be resiniferous; they range in height from 2 to 17 cells and consist prevailingly of alternations of rays 2 to 4 cells high with those of rays 6 to 8 cells high. There are rarely four rows of tracheids between adjacent rays, the normal number being two. The xylem parenchyma, as in the radial sections, is generally bordered by rays. The tangential walls of the tracheids are marked with circular-bordered pits about one-half the size of the pits on the radial walls. These pits are usually in a single row and well spaced, but they may be in juxtaposition for a short distance or in double rows, either in pairs or alternating for short distances, as shown in the enlarged figure. In this section the rotted and spirally fractured walls of the tracheids are very obvious, and care is necessary to distinguish them when in this condition from normal spirally thickened tracheids, which are not present in this genus. In this section the cross sections of the bordered pits of the radial walls of the tracheids often come out beautifully, and they can even be seen in the figure enlarged but 20 times.

This well-marked species is perfectly distinct from Cupressinoxylon calli, described by Knowlton ${ }^{8}$ from material collected in beds of possible Wilcox age in Arkansas. It also appears to be unlike the rather numerous described species of Cupressinoxylon from other horizons or areas. The incompleteness of large numbers of the descriptions of previously known forms renders detailed comparisons futile. The distinction between the present species and those forms of fossil wood referred to the genus Podocarpoxylon Gothan, as amended by Stopes ${ }^{9}$ to inclúde Gothan's Podocarpoxylon and Phyllocladoxylon, are not especially obvious and rest on the size, form, and number of the pits on the radial walls of the ray cells, which are larger, fewer, and more eccentric in Podocarpoxylon. More recently Seward ${ }^{10}$ has proposed the form genus Mesembrioxylon for these. These differences are all relative and hardly generic in character, as a series of species can be selected which connect the extremes.

In the present state of our knowledge of wood anatomy, even among the comparatively well known group of conifers, it is not feasible to attempt to point out the most closely allied existing representative of the present species.

The genera Glyptostrobus and Taxodium are represented by foliage and seeds in the Wilcox, and it may well be that this abundant wood type represents one or the other of these genera.

Occurrence: Caddo and De Soto parishes, La. Figured specimens, northwest corner sec.

8 Knowlton, F. H., Arkansas State Geologist Ann. Rept. for 1889, vol. 2, p. 254, pl. 9, figs. 3-7, 1891.

9 Stopes, M. C., The Cretaceous flora: British Mus. Cat., pt. 2, p. 210, 1915.

${ }_{10}$ Seward, A. C., Fossil plants, vol. 4, p. 173, 1919. 
36 , a quarter of a mile south of Slaughter Pen Bluff, Caddo Lake (201); Shreveport (210, 269). Other specimens, Slaughter Pen Bluff, Caddo Lake (203); 6 miles southeast of Naborton (205, 206); $4 \frac{1}{2}$ miles southeast of Naborton (216); 4 miles southeast of Naborton (208) ; 3 miles southeast of Naborton $(209,211) ; 2 \frac{1}{4}$ miles southeast of Naborton (204); 1 mile southeast of Naborton (268); half a mile southeast of Naborton (213); 6 miles southeast of Mansfield (270); $1 \frac{1}{2}$ miles north of Mansfield (266).

\section{Phylum ANGIOSPERMOPHYTA.}

\section{Class MONOCOTYLEDONAE.}

Order ARECALES.

Family ARECACEAE.

Genus PALMOCARPON Lesquereux.

Palmocarpon butlerensis Berry, n. sp.

Plate IV, figures 2-4.

Fruit apparently a small, thin-fleshed drupe, in form a prolate spheroid - the long diameter less than one-half greater than the short diameter. Varying considerably in size. Surface of the stone dark in color (possibly a secondary feature), conspicuously papillose. Hilum large. Minimum dimensions 4 by 5 millimeters; maximum 14 by 18 millimeters. Abundant but generally slightly deformed. Specific name in allusion to the name of the salt dome from which the material was collected.

This form is very similar to Palmocarpon truncatum, from Golden, Colo., described by Lesquereux in 1878 and supposed to have come from the Denver formation. There is the same variation in size in both, and although Lesquereux makes the flattening of the Golden specimens a specific character this is of doubtful validity, as he states that the specimens were generally crushed. I would have referred these Wilcox fruits to Palmocarpon truncatum except for the definite and repeated statement by Lesquereux that the Golden form was smooth, which the Wilcox form is not. In any event the two are closely related. Lesquereux ${ }^{11}$ compared the Golden forms with the fruits of the existing Sabal mexicana Martius, and similarly the Wilcox fruits may be those of Sabal. Leaves of Sabalites grayanus Lesque-

\footnotetext{
"11 Lesquereux, Leo, The Tertiary flora: U. S. Geol. Survey Terr.
} Rept., vol. 7, p. 120, pl. 11, figs. 6-9, 1878. reux are widespread in the Wilcox, but they are not conclusively known to be related to Sabal. Moreover, very many modern palms have racemes of small fruits very similar to the present fossils. To mention but a few familiar existing species with fruits very close to the fossil I may cite our dwarf saw palmetto, Serenoa serrulata (Michaux) Hooker; the royal palm, Roystonea regia (H. B. K.) Cook; the goose-neck palmetto, Sabal etonia Swingle; and the cabbage palmetto, Sabal palmetto (Walter) Roemer and Schultes.

Occurrence: Butler salt dome, 6 miles northeast of Oakville, Freestone County, Tex.; 4 miles southwest of Boydsville, Ark.; Carrizo sandstone half a mile west of Carrizo Springs, Dimmit County, Tex.

\section{Class DICOTYLEDONAE.}

Order URTICALES.

Family MORACEAE.

Genus ARTOCARPOIDES Saporta.

Artocarpoides balli Barry, n. sp.

Plate IV, figures 8-10; Plate V.

Leaves of variable size, ovate, with a broadly rounded base, which is sometimes slightly inequilateral, and a narrowed and apiculate tip. Margins entire, slightly undulate. Texture subcoriaceous. Petiole invariably missing. Midrib stout, very prominent on the lower surface of the leaf. Secondaries stout and prominent, 9 to 15 pairs, opposite to alternate, approximately equally spaced and subparallel, the basal one or two pairs at right angles to the midrib, becoming regularly more ascending toward the upper part of the leaf, relatively straight at first, becoming curved in the marginal region and eventually camptodrome close to the margins. Tertiaries well marked, closely spaced, percurrent. Areolation well marked, quadrangular.

The smallest leaves referred to this species are only 4 centimeters in length and 2 centimeters in maximum width; the largest is 24 centimeters in length and 10 centimeters in maximum width. There are six specimens of various sizes in the collection, and all preserve their specific features unchanged. The type is well marked and clearly different from previously described members of the Wilcox flora. A species from Puryear, Tenn., was 
described as Artocarpoides wilcoxensis. ${ }^{12}$ This was more elliptical in outline, widest medianly and pointed at both ends, with fewer, thinner secondaries, less closely set tertiaries, and more open areolation.

The genus Artocarpoides was founded by Saporta for certain forms from the Paleocene of Sézanne, France, that he compared with the existing entire-leafed species of Artocarpus, which they really greatly resemble. Schenk ${ }^{13}$ considered them to be related to the Juglandaceae, but I fail to see any basis for this comparison. Among the French forms a considerable resemblance to the present species is shown by Artocarpoides conocephatoidea Saporta, ${ }^{14}$ a relatively small form, and a very great resemblance by Protoficus sezannensis Saporta $^{15}$ and $P$. insignis Saporta. ${ }^{16}$ Among existing forms of Moraceae considerable resemblance is also shown by the tropical American genus Brosimum Swartz, which ranges from the West Indies and Central America to Brazil, and the tropical American genus Coussapoa Aublet, which has about 15 existing species with a similar range and which is found fossil in the Tertiary of Venezuela, southern Mexico (Miocene and Pliocene), and Bolivia. For example, the present species resembles a tropical American leaf figured by Ettingshausen and called Artocarpus rigida Linné. Whether Ettingshausen confused the oriental Artocarpus rigida of Blume or whether his leaf was an Ameriean species of Coussapoa or some related genus I do not know, nor is it material, for in any case the resemblance between the fossil and certain recent Moraceae is emphasized.

It is possible that these Wilcox forms are more closely related to these last-named genera than they are to Artocarpus, but they are surely referable to the Moraceae.

The present species is named for the collector, Prof. O. M. Ball.

Occurrence: Goss pit, half a mile east of Mansfield, De Soto Parish, La.; collected by O. M. Ball.

\footnotetext{
12 Berry, E. W., U. S. Geol. Survey Prof. Paper 91, p. 194, pl. 109 fig. $5,1916$.

13 Schenk, August, Palaeophytologie, pp. 451, 477, 1890

14 Saporta, G. de, op. cit., p. 68, pl. 7, fig. 6, 1868.

${ }^{15}$ Idem, p. 67, pl. 6, fig. 1.

${ }^{16}$ Idem, p. 68 , pl. 6, figs. 2-4.
}

\section{Genus FICUS IINNE.}

Ficus mississippiensis (Lesquereux) Berry.

Plates VI, VII, and VIII.

Cinnamomum mississippiensis Lesquereux, in Dana, Manual of geology, 1st ed., p. 513, fig. 794, 1866; Am. Philos. Soc. Trans., vol. 13, p. 418, pl. 19, fig. 2, 1869.

Knowlton, Am. Geologist, vol. 16, p. 308, 1895; U. S. Geol. Survey Prof. Paper 101, p. 320, pl. 89, fig. 2, 1917.

Berry, U. S. Geol. Survey Prof. Paper 91, p. 298, pl. 37, fig. 2, 1916.

Ficus planicostata Lesquereux, U. S. Geol. and Geog. Survey Terr. Ann. Rept. for 1872, p. 393, 1873; Tertiary flora, p. 201, pl. 31, figs. 1-8, 10-12, 1878.

?Newberry, U. S. Geol. Survey Mon. 35, p. 88, pl. 46, fig: 1, 1898.

Cockerell, Colorado Univ. Studies, vol. 7, p. 151, 1910. Ficus clintoni Lesquereux, U. S. Geol. and Geog. Survey Terr. Ann. Rept. for 1872, p. 393, 1873.

Ficus planicostata goldiana Lesquereux, idem for 1873, p. 399 , 1874; Tertiary flora, p. 202, pl. 33, figs. 1-3, 1878.

Ficus pseudopopulus Lesquereux, U. S. Geol. and Geog. Survey Terr. Bull., vol. 1, p. 387, 1875; idem, Ann. Rept. for 1874 , p. 313, 1876; Tertiary flora, p. 204, pl 34, figs. 1a, 2.

Berry, U. S. Geol. Survey Prof. Paper 91, p. 200, pl. 37, figs. 3-5; pl. 113, fig. 3, 1916.

Knowlton, U. S. Geol. Survey Prof. Paper 101, p. 304, pl. 72, figs. 2-4; pl. 73, figs. 1, 2; pl. 112, fig. 3, 1918.

Ficus occidentalis (Lesquereux) Lesquereux, Tertiary flora, p. 200, pl. 32, fig. 4, 1878; Mus. Comp. Zool. Bull., vol. 16, p. 50, 1888 .

Penhallow, Report on Tertiary plants of British Columbia, p. 55, 1908.

Berry, U. S. Geol. Survey Prof. Paper 91, pp. 121, 197, pl. 28, fig. 3, 1916.

Knowlton, U. S. Geol. Survey Prof. Paper 101, p. 331, pl. 72, fig. 1, 1918.

Dombeyopsis occidentalis Lesquereux, U. S. Geol. and Geol. Survey Terr. Ann. Rept. for 1872, p. 380, 1873.

Ficus planicostata clintoni Knowlton, U. S. Geol. Survey Bull. 152, p. 103, 1898; U. S. Geol. Survey Prof. Paper 191, p. 303, pl. 76, fig. 3, 1918.

Ficus planicostata latifolia Lesquereux, U. S. Geol. and Geog. Survey Terr. Ann. Rept. for 1872 , p. 393, 1873; Tertiary flora, p. 202, pl. 31, fig. 9, 1878.

Berry, U. S. Geol. Survey Prof. Paper 91, p. 199, 1916. Ficus latifolia Knowlton (not Kunth, 1846), U. S. Geol. Survey Bull. 152, p. 102, 1898; U. S. Geol. Survey Prof. Paper 101, p. 304, 1917.

Ficus cockerelli Knowlton, U. S. Geol. Survey Bull. 696, p. 273, 1919.

Ficus planicostata maxima Berry, U. S. Geol. Survey Prof. Paper 91, p. 199, pl. 34, fig. 3, 1916.

Ficus planicostata Lesquereux. Hollick, Louisiana Geol. Survey Special Rept., p. 282, pl. 36, 1888. 
Ficus neoplanicostata Knowlton, U. S. Geol. Survey Prof. Paper 101, p. 303, pl. 73, fig. 4; pl. 74, figs. 2, 3; pl. 76, fig. 4, 1918.

Berry, U. S. Geol. Survey Prof. Paper 91, p. 198, pl. 114, fig. 1, 1916.

Ficus richardsoni Knowlton, U. S. Geol. Survey Prof. Paper 101, p. 305, pl. 76, fig. 1, 1918.

It would seem that if the systematic work of paleobotany is to be made available for the general purposes of geology and botany the paleobotanist must take the time to coordinate and digest the results of the work on local floras. There are certain general principles that should guide workers in founding new species, and I am thoroughly in accord with the principle which holds that analysis should precede synthesis, and that in describing specimens from a new horizon or a remote geographic locality the presumption should prevail that they are distinct from previously described forms unless identity can be conclusively shown. Likewise there are certain forms in a different category, long known and hence not susceptible of this treatment-for example, Podozamites lanceolatus, Asplenium dicksonianum, or Sequoia reichenbachi-which are obviously composite and yet which do not offer any criteria for segregation other than those of a stratigraphic nature. These forms may well remain as they are until the progress of knowledge enables the paleobotanist to treat them in a scientific manner.

In a recent study of a large and well-preserved collection from the Wilcox near Mansfield, La., I have been profoundly impressed with the graded variability in the leaves of certain genera, particularly Ficus and Rhamnus. In my report on the flora of the Wilcox group, published in 1916, 18 different species of Ficus were recognized, and in Knowlton's recently published report on the flora of the Raton formation 17 species of Ficus are recognized. In both works the comparisons made appear legitimate, but in neither, apparently, had the broader question of interrelationship in the genus received adequate consideration. To revert to the representation of Ficus in the Wilcox flora: Of the 18 identified forms a reexamination appears to confirm the validity of 13 beyond question. The remaining five species, which were identified as Ficus neoplanicostata, pseudopopulus, planicostata maxima, occidentalis, and denveriana, represent ovate types with three basilar or subbasilar primaries and percurrent tertiaries. As sparingly represented in the original collections each showed a certain individuality, but in the later collection, where they are abundant, they show every gradation in size and in the ratio of width to length.

I do not consider it possible to maintain specific boundaries in this series, although the extremes of size or of short-elliptical or long and narrow ovate-acuminate outline are strikingly different in aspect.

This polymorphism, or better termed variability, led to the assembling of all the published figures of the so-called species enumerated in the foregoing synonymy. It was found that these forms had been described at different times by different workers and that the criteria of separation were as follows:

1. Size.

2. Relative proportions of width to length.

3. Shortening or lengthening of the apex.

4. Character of base ranging from various degrees of cuneate through truncate to slightly cordate.

5 . Number and spacing of the secondaries.

6. Position of the primaries, whether basilar, subbasilar, or suprabasilar.

In all the species the general facies and tertiary venation remain identical throughout. It might be argued that these represent generic features and that the foregoing criteria of separation are legitimate specific features. It may be noted, however, that most of the features enumerated above are interrelated and dependent upon the proportions of the leaves, and it may also be noted that leaves which are normally large at maturity reach that normal size by growth, so that mere smallness is not a specific character. However, I will not quarrel with my colleagues who prefer to keep the species listed in the foregoing synonymy distinct-the relationships sketched below hold good, whatever categories are used. Some will doubtless incline to consider them varieties of a single botanic species, but I can only think of them as varieties in the praenuntial or formative state, with the intermediate steps not yet extinct, and it seems to me that all could probably have been found on a single lower Eocene tree. Were they ever found unassociated there might be some justification for maintaining their distinctness, but wherever adequate col- 
lections are available, whether it be from the Denver formation, the Raton formation, or the Wilcox group, all or nearly all the forms are found associated in the same stratum. Fifteen to twenty species of a single genus do not grow together in nature.

If these forms are considered to represent a single variable species, then the earliest name available is mississippiensis, given by Lesquereux to what he regarded as a species of Cinnamomum. It is true that this form was rather small in size, but the type is no longer in existence and the later material identified as this species is larger. For example, the form so named in the Raton flora is identical with the associated forms referred to Ficus pseudopopulus. The type of this last-mentioned species was also based on small forms, which do not, however, differ in any essential respect from the larger leaves later determined, and the maximum of size and elongation is furnished by the forms from the Wilcox figured in the present contribution. I have not included Ficus denveriana in the foregoing synonymy, as it prevailingly lacks the three primaries and is pinnate veined. However, certain specimens so called appear to belong here, as, for example, the specimen shown in figure 5 on Plate XXXIII of Lesquereux's "Tertiary flora." mississippiensis would be the transformation of the basal secondaries into lateral primaries. As triveined forms of Ficus are not uncommon in the Upper Cretaceous the ancestral stock of Ficus mississippiensis may go back to some such form as Ficus ovatifolia Berry, of the Coastal Plain Cretaceous, or Ficus praetrinervis Knowlton, of the Vermejo formation, and Ficus denveriana may be unrelated or else represent the transformation of lateral primaries into basal secondaries.

Discussion may be eliminated by presenting the supposed interrelationship diagrammatically in terms of the specific names of the above synonymy, as follows:

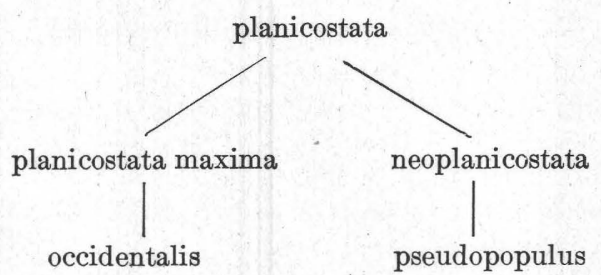

The maxima of these two lines of variation are shown in the accompanying figures, and no detailed description of them is regarded as necessary. A statement regarding the recorded geographic and geologic range of the species may not, however, be out of place. This may be presented in tabular form, as follows:

\begin{tabular}{|c|c|c|c|c|c|c|}
\hline & Laramie. & Wilcox. & Raton. & $\begin{array}{c}\text { Post-Laramie, } \\
\text { Black Buttes } \\
\text { coal group, or } \\
\text { Evanston. }\end{array}$ & Clarno. & Denver. \\
\hline 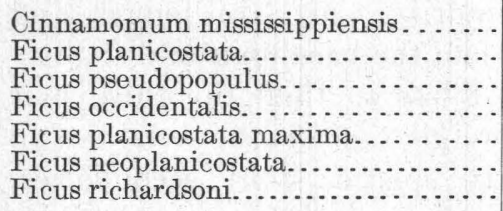 & ${ }^{\cdots}{ }^{\cdots}$ & $\begin{array}{l}x \\
(?) \\
x \\
x \\
x \\
x \\
\cdots\end{array}$ & $\begin{array}{l}x \\
x \\
x \\
x \\
x \\
x\end{array}$ & 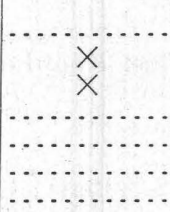 & 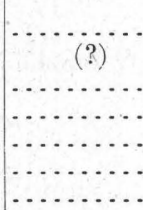 & 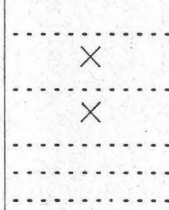 \\
\hline
\end{tabular}

Ficus planicostata Lesquereux represents variants with a foreshortened apex, although the smaller leaves of this so-called species as figured by Lesquereux are indistinguishable from the small leaves of Ficus neoplanicostata figured by Knowlton.

If the central stock of this variable species is considered to have been an elliptical-ovate penniveined form similar to the typical Ficus denveriana Cockerell or to the young leaves referred to Ficus neoplanicostata, then the assumption of the specific character of Ficus
It may be noted that only one of these species, namely, $F$. planicostata, is recorded from a pre-Tertiary horizon, and that all are found associated in both the Wilcox and Raton floras, Ficus richardsoni Knowlton of the Raton not being an exception to this statement, for it is obviously identical with Ficus pseudopopulus. Occurrences in the Wilcox range throughot:t the group and are as follows:

Ackerman formation: Raglans Branch, Lafayette County, Miss.; Colemans Mill, Choctaw County, Miss.; Hurleys, Benton County, Miss. 
Upper Wilcox: Shreveport, Caddo Parish, La.; Mansfield, Naborton and vicinity, De Soto Parish, La.; Old Port Caddo Landing, Harrison County, Tex.; Elmendorf clay pit, Elmendorf, Bexar County, Tex.; Carrizo sandstone half a mile west of Carrizo Springs, Dimmit County, Tex.

Lagrange formation (middle and upper Wilcox age): Puryear, Henry Cointy, Tenn.; Sandy, Hardeman County, Tenn.

\section{Order RANALES.}

\section{Family MAGNOLIACEAE.}

Genus MAGNOLIA Linnê.

Magnolia angustifolia Newberry.

Plate IX.

Magnolia angustifolia Newberry, U. S. Nat. Mus. Proc., vol. 5, p. 513, 1882.

Berry, U. S. Geol. Survey Prof. Paper 91, p. 214, 1916.

Knowlton, U. S. Geol. Survey Prof. Paper 101, p. 309, pl. 79, fig. 1; pl. 80; pl. 81, fig. 1, 1917.

Magnolia attenuata Weber. Lesquereux, Tertiary flora, p. 250 , pl. 45 , fig. 6,1878 .

Terminalia radobojensis Heer (not Unger). Lesquereux, U. S. Geol. and Geog. Survey Terr. Ann. Rept. for 1871, Suppl., p. 15, 1872.

Magnolia lanceolata Lesquereux. Hollick, Louisiana Geol. Survey Special Rept. 5, p. 282, pl. ii, 1899.

This species, which is common in the Raton formation and in the upper part of the Wilcox group, is much more common west of the Mississippi than east of it. A specimen from Louisiana is figured in the present paper.

Occurrence: Goss pit, half a mile east of Mansfield, De Soto Parish, La.; collected by O. M. Ball.

\section{Magnolia leei Knowlton.}

Plate X.

Magnolia leei Knowlton MS. Berry, U. S. Geol. Survey Prof. Paper 91, p. 215, pl. 43, figs. 1, 2, 1916.

Knowlton, U. S. Geol. Survey Prof. Paper 101, p. 313, pl. 64 , fig. 2 ; pl. 65 , fig. 2 ; pl. 81 , fig. $2,1918$.

This well-marked species, which is abundant in the Raton formation in Colorado and New Mexico, appears to range from the bottom to the top of the Wilcox group in the embayment region. It has not heretofore been found in that region west of the Mississippi but proves to be not uncommon in Louisiana.

Occurrence: Goss pit, half a mile east of Mansfield, De Soto Parish, La.; collected by O. M. Ball.
Family MENISPERMACEAE.

Genus MENISPERMITES Lesquereux.

Menispermites cebathoides Berry, n. sp.

Plate XI, figure 1.

Leaves orbicular-ovate, about as wide as long, with a wide truncate base and a broadly and shortly pointed apex. Margins entire. Texture thin. Length about 10 centimeters; maximum width, below the middle, about 10 centimeters. Petiole missing, but from the character of the basse it must have been of considerable length and expanded where it joined the lamina; the joint was at an angle with the plane of the lamina. There are 7 primaries from the widely expanded apex of the petiole at the extreme base of the leaf. These diverge at acute regularly spaced angles; all are curved, and the midrib is slightly, if at all, stouter than the lateral primaries. It is longer, however, and at about one-third of its distance to the apex it gives off, at acute angles, a pair of opposite secondaries, which sweep upward and are camptodrome in the tip of the leaf. The lateral primaries are all stout and prominent and decrease in length from above downward. The basal, shortest, and straightest pair form angles of about $70^{\circ}$ with the midrib; they give off on the outside three or four regularly spaced secondaries, which are camptodrome close to the margin; the tip joins the tip of the basal secondary of the primary next above by a simple camptodrome arch close to the margin. The second pair of primaries form angles of about $50^{\circ}$ with the midrib; they are longer and slightly stouter than the basal pair and slightly more curved, but less so than the third pair of primaries; they give off on the outside two to four regularly spaced stout secondaries, which are camptodrome close to the margin; their tip joins a simple camptodrome tertiary from the lowest secondary of the third primary by a simple camptodrome curve close to the margin. The third pair of primaries form angles of about $25^{\circ}$ with the midrib; they are more curved than the others and give off on the outside four or five regularly spaced secondaries, which are simply camptodrome close to the margins and the basal one of which may have the caliber and appearance of a dichotomous fork of the primary, as in the left side of the leaf figured; the tip of the third primary 
curves close to the margin to join a camptodrome tertiary from the outside of the main pair of secondaries from the midrib. The tertiaries, with the exception of the camptodrome ones already alluded to, are thin and largely immersed, exceedingly regular in their spacing, and prevailingly percurrent, although they occasionally fork and inosculate, as shown in the figured specimen. The ultimate areolation is fairly distinct in spots and must have been entirely so in life; it shows relatively large and prevailing subrectangular meshes.

This fine species is obviously new and forms a striking addition to the Wilcox flora, as its modern relatives are all climbing or twining herbs or shrubs prevailingly of wooded or stream-side habitats. It is similar in form to the Wilcox species Cercis wilcoxiana Berry but entirely different in its venation characters and obviously not related to that form. The previously known Wilcox species of Menispermites, M. witcoxensis Berry, is a much more typically ovate form with a prolonged acuminate tip and but three instead of seven primaries. The tertiary venation and the camptodrome arches close to the margins are the same in both, and neither shows the tendency toward a lobation of the lamina, which is so pronounced a feature in so many of the existing species of this family.

The existing species are too imperfectly known and polymorphous to render detailed comparisons with this Eocene form of much value. The fossil is not unlike the leaves of our common Menispermum canadense Linné, which are nonlobate. It shows a similar resemblance to the leaves of our common Cebatha carolina (Linné) Britton, which are nonlobate, and similar statements might be made with regard to a large number of existing species of the family. Among fossil forms the most similar is Cocculus (Cebatha) latifolius, from the Pliocene of France, described by Saporta and Marion, ${ }^{17}$ but this similarity is of the same order as the comparisons with recent forms just mentioned.

The polymorphism of the existing species renders it desirable to refer this new form to the genus Menispermites, implying a fossil form of Menispermaceae of undeterminable generic affinity. It might very well be ancestral to the

${ }^{17}$ Saporta, G. de, and Marion, A.F., Recherches sur les végétaux fossiles de Meximieux, p. 264, pl. 31, figs. 4-7; pl. 32, fig. 1, 1876. $91048^{\circ}-23-2$ genus Cocculus De Candolle, or Cebatha Forskal, as modern taxonomists prefer to call it, as Forskal's name was published in 1775 , or 43 years earlier than De Candolle's proposal.

The existing species of Menispermaceae number about 350 in about 60 genera. All are twining or climbing woody or herbaceous plants with alternate exstipulate leaves and drupaceous fruits. A majority of the species are confined to moist tropical regions, but a considerable number are found in both temperate zones. None of the subfamilies are confined to a single continental region, and several of the genera are found on all the continents.

The existing species of Menispermum, but two or three in number, are confined to Atlantic North America and eastern Asia, which indicates a wider range during geologic time. The genus Cebatha (Cocculus) is a large one for this family, with about 30 species, its distribution including all the continents except Europe and extending to the Hawaiian Islands. Several fossil species that have been referred directly to it or to the form genus Cocculites go back as far as the Upper Cretaceous. A wellmarked species is present in the later Tertiary of the Mississippi embayment, and it would perhaps not be far from the truth if the present species were referred to this genus.

The family has 10 genera with about 75 species confined to the Western Hemisphere, mostly in tropical South America. Asia has 13 peculiar genera; Africa, including Madagascar, has 14; and Australia has 7, all monotypic and largely found in the peculiar environment of Western Australia. The largest number of existing species occur in tropical Asia, from which about 150 are known, or about 50 more than are known from America, which ranks second in the number of existing forms.

The fossils of the narrow triveined form of some species of Cocculus (Cebatha) are rather difficult to determine, for they show more or less resemblance to some leaves in the families Smilacaceae, Lauraceae, Urticaceae, Piperaceae, Melastomataceae, and others.

The wider leaves are more characteristic, and species of Menispermum are recorded from beds as early as the Oligocene of France. The form genus Menispermites has numerous Upper Cretaceous species, particularly of Cenomanian and Turonian age, and is recorded 
from Portugal, Bohemia, Greenland, Argentina, and various localities in the United States and Canada. It is especially varied in the Dakota sandstone.

Forms referred to Cocculus De Candolle, Cocculites Heer, or Cebatha Forskal are recorded from the Upper Cretaceous of North America, Europe, and Asia and from the early Tertiary of Greenland, North America, and Europe. It seems probable that some of the forms referred to Unger's genus Daphnogene belong to this family. The genus Macclintockia Heer, of the Upper Cretaceous and early Tertiary, particularly of the Arctic region, is often referred to this family, as by Schimper.

Occurrence: Goss pit, half a mile east of Mansfield, De Soto Parish, La.; collected by O. M. Ball.

\section{Order ROSALES.}

Family CAESALPINIACEAE.

Genus CASSIA Linne.

Cassia emarginata Berry.

Cassia emarginata Berry, U. S. Geol. Survey Prof. Paper 91, p. 233, pl. 45 , fig. $17 \mathrm{~b}$; pl. 48, fig. 5, 1916.

Heer ${ }^{18}$ mentions a Cassia emarginata of Saporta, which would, if valid, necessitate changing the name of this Wilcox species. As near as I can discover, however, Cassia emarginata Saporta was a nomen nudum. It is not mentioned by either Schimper or Schenk, and Saporta appears to have renamed the form Caesalpinites latifolius when he actually described it. ${ }^{19}$

Family MIMOSACEAE.

\section{Genus MIMOSITES Bowerbank.}

\section{Mimosites variabilis Berry.}

Mimosites variabilis Berry, U. S. Geol. Survey Prof. Paper 91, p. 227, pl. 45, figs. 6-11, 1916.

This common middle and upper Wilcox species has not heretofore been found south of Grenada, Miss. It is contained in recent collections from a locality 1 mile west of Clayhatchee, Dale County, Ala.

\footnotetext{
18 Recherches sur le climat et la végétation du pays tertiaire, p. 149, 1861.

19 Saporta, G. de, Études sur la végétation du sud-est de la France à l'époque tertiaire, vol. 1, p. 140, 1863.
}

Family PAPILIONACEAE.

Genus DALBERGIA Linné fils.

Dalbergia puryearensis Berry, new name.

Dalbergia eocenica Berry, U. S. Geol. Survey Prof. Paper 91, p. 245, pl. 53, figs. 1, 2, 1916.

The name assigned to this Wilcox Dalbergia in 1916 is antedated by Dalbergia eocenica Ettingshausen,$^{20}$ based on Protamyris eocenica Unger, ${ }^{21}$ and I therefore propose that this species be called Dalbergia puryearensis, in allusion to the type locality.

Order SAPINDALES.

Family ICACINACEAE.

Genus CALATOLOIDES Berry, n. gen.

Calatoloides eocenicum Berry, n. $\mathbf{s}^{n}$

Plate XIV, figures 3-5.

The present species is based on casts of a nutlike fruit which appears to be very close to those of a recently described genus that is referred with some doubt to the family Icacinaceae and is based upon three new species of existing arborescent forms of the Central American region. In view of the incompleteness of the fossil material and the lack of certainty as to its identity with the recent fruits in all particulars, it has seemed best to propose a new genus for its reception. The name suggested for this new genus implies a relationship with the existing genus. The fossil fruit as restored from casts is a moderately prolate spheroid, 2.5 to 3 centimeters in length and about 2.25 centimeters in diameter, broadly rounded proximad and bluntly pointed distad. The ligneous shell is marked by somewhat irregular prominent branching and anastomosing longitudinal ridges, connected by low subordinate irregularly transverse ridges. If it was like the existing form it contained a single large seed.

I have had this Wilcox material in my possession for a number of years without any idea as to its botanic relationship. In collecting recent fruits in Panama in 1919 I obtained one which suggested the fossil. In seeking to determine the Panama specimen at the United

${ }^{20}$ Ettingshausen, Constantin, Beiträge zur Kenntniss der fossilen Flora von Sotzka, p. 73, 1858.

${ }^{21}$ Unger, Franz, Die fossile Flora von Sotzka, p. 180, pl. 31, fig. 15, 1850. 
States National Herbarium I found that it was identical with material from Costa Rica which Messrs. Standley and Safford considered to represent a new genus, very probably a member of the Icacinaceae. They have since recognized three species of this genustwo from Mexico and one from Costa Rica and Panama. These are trees of considerable size, with broadly lanceolate camptodrome-veined leaves. The fruits have a thin flesh in life and a single large spherical seed. The fossil form is similar in shape and ornamentation but is only about half the size of the recent fruits and may therefore be considered as standing in an ancestral relation to the modern genus, for which Standley and Safford have proposed the name Calatola.

The occurrence of a fossil representative of the family Icacinaceae in the lower Eocene of Texas is of very great interest. No member of the family, so far as I know, has ever before been found fossil. The family consists of about 39 genera and 150 existing species, of which only 8 genera, with less than 30 species, are found in America, where they are for the most part confined to the Tropics. None of these genera except Mappia, a native of the Antilles, occurs in any other geographic region, and this genus is supposed to be represented in Ceylon and farther India. As the forms from farther India constitute the subgenus Trichocrater and those from Ceylon the subgenus Eumappia, it seems doubtful if Mappia is really an exception to the peculiar character of the existing American members of this family. The family as a whole is distinctly oriental in the existing flora, with its center of dispersal in the south Asian region, for although there is only a single monotypic genus confined to southeastern Asia, this region pairs with Africa, the East Indies, or Australia in many occurrences: thus there are 8 genera with 23 species which are Malaysian, 6 genera with 34 species which are Asian and Malaysian, 3 genera with 19 species which are common to Africa and southern Asia, and 1 genus with 4 species common to Malaysia and Australia. Ten genera with 33 species are confined to Africa, and 3 genera with 6 species are confined to Australia.

The family contains 10 monotypic generaone of Guiana and all the remainder Old World forms, as follows: Africa 3, southeastern Asia 1,
East Indies 2, New Guinea 1, New Caledonia 2. All the existing American forms belong to the large subfamily Icacinoideae, which is also represented in all the other regions, so that its origin or interrelationships are unknown.

Occurrence: Butler (West Point) salt dome, in the eastern part of Freestone County, near Trinity River, 6 miles northeast of Oakville, Tex.; collected by O. B. Hopkins and O. C. Funderbunk.

\section{Order RHAMNALES.}

Family RHAMNACEAE.

Genus RHAMnUs Linné.

Rhamnus cleburni Lesquereux.

Rhamnus cleburni Lesquereux, U. S. Geol. and Geog. Survey Terr. Ann. Rept. for 1872, p. 381, 1873; Tertiary flora, p. 280, pl. 53, figs. 1-3, 1878; U. S. Nat. Mus. Proc., vol. 11, p. 24, 1888.

Knowlton, U. S. Geol. Survey Bull. 204, p. 80, 1902.

Berry, U. S. Geol. Survey Prof. Paper 91, p. 283, 1916.

The present material, which is abundant, emphasizes the great similarity and possible identity between this form and Rhamnus coushatta. Berry, ${ }^{22}$ also the great variability in outline of these leaves, many of which are longer and relatively narrower than the type and show indications of grading into what I have called Rhamnus marginatus apiculatus. ${ }^{23}$

Occurrence: Goss pit, half a mile east of Mansfield, De Soto Parish, La.; collected by O. M. Ball.

Rhamnus marginatus apiculatus Berry.

Plate XI, figures 2, 3 .

Rhamnus marginatus apiculatus Berry, U. S. Geol. Survey Prof. Paper 91, p. 283, pl. 69, fig. 1, 1916.

At the time of the publication of the report on the Wilcox flora this variety was represented by a small number of specimens from the Ackerman formation of Mississippi. It is common in later collections from Louisiana and shows considerable variation in size and outline. All the specimens are somewhat narrower than the type; some have a very long acumen and others lack a prominent acumen. Two of these specimens are figured, the larger a leaf 21 centimeters in length and 4 centimeters in maximum width.

${ }_{22}$ Berry, E. W., U. S. Geol. Survey Prof. Paper 91, p. 284, pl. 68, fig. 1 1916.

${ }^{23}$ Idem, p. 283, pl. 69, fig. 1. 
Occurrence: Goss pit, half a mile east of Mansfield, De Soto Parish, La.; collected by O. M. Ball.

\section{Genus RHAMNITES Forbes.}

Rhamnites knowltoni Berry, new name. Plate XII, figure 7.

Cornus studeri Lesquereux, U. S. Geol. and Geog. Survey Terr. Ann. Rept. for 1871 , p. 293, 1872 (not Heer, 1859); Tertiary flora, p. 244, pl. 42, figs. 4, 5, 1878.

Hollick, in Harris and Veatch, A preliminary report on the geology of Louisiana, p. 286, pl. 45, fig. 2, 1899.

Knowlton, U. S. Geol. Survey Bull. 163, p. 68, pl. 15, fig. $3,1900$.

Berry, U. S. Geol. Survey Prof. Paper 91, p. 331, pl. 68, fig. 3, 1916.

In the account of the Wilcox flora this species was said to be represented by fragments from a number of localities, the most complete specimen being the one figured from Coushatta, La. Subsequent collections show that this form is abundant in the Wilcox near Mansfield and confirm the previous statement that it differs from Heer's Swiss Miocene type and also is not properly referable to the genus Cornus. Although in some of the features it is similar to species that have been referred to Ficus, these features are not like any in existing forms of that genus, where the venation has certain characteristics that are easily recognized. They are, on the other hand, characteristic of certain members of the families Sapindaceae and Rhamnaceae, particularly the latter, and I have therefore transferred the American forms to the genus Rhamnites.

$R$. knowltoni may be described as follows:

Leaves large, broadly ovate, many of them slightly inequilateral, the tip somewhat narrowed and acuminate and the base rounded or very broadly pointed. Margins entire, in some specimens faintly undulate. Texture subcoriaceous. Midrib stout and prominent. Secondaries stout, six to nine pairs, diverge from the midrib at irregular intervals at angles of about $45^{\circ}$, camptodrome. Tertiaries thin, closely spaced, percurrent, typically rhamnaceous. Size variable, some leaves being as much as 19 centimeters in length and 9.5 centimeters in maximum width, which is in the lower half of the leaf. A large specimen from Mansfield is figured in the present paper. The single Louisiana specimen has a length of 16 centimeters and a maximum width, midway between the apex and the base, of 8.75 centimeters.
Occurrence: Goss pit, half a mile east of Mansfield, De Soto Parish, La.; collected by O. M. Ball.

Order MALVALES.

Family MALVACEAE?

Genus MONOCARPELLITES Perkins.

[Vermont State Geologist Rept. for 1903-4, p. 180.]

Monocarpellites perkinsi Berry, n. sp.

Plate XII, figures 1-6.

Ligneous single-celled carpels, with numerous seeds. General form spheroidal; whether oblate or prolate is uncertain, as the material has suffered much compression. Probably nearly spheroidal in life, with 10 to 12 thin longitudinal ribs. Apex mucronate-tipped. Hilum large depressed, about 2 millimeters in diameter.

This species is not uncommon at the locality cited, but it is impossible to determine the character of the interior. The conclusion that the ribs do not represent keels or sutures of a tardily dehiscent capsule rests upon their somewhat unequal spacing, the lack of any traces of sutures, and the fact that one specimen has undergone great compression in a vertical plane without developing any indications of a capsular nature. The conclusion that these carpels were many seeded also rests upon the manner in which compression has occurred and the resulting irregularities of surface, which differ from what would be shown if one or a few large seeds had been present.

The genus Monocarpellites, to which the present species is referred, is a form genus established by Perkins in 1904 and based upon abundant material from the Eocene lignite deposits at Brandon, Vt. Specimens of Monocarpellites are among the most abundant fossils at Brandon, and Perkins has described 11 different species based upon differential features that are more or less well marked but quite obviously not of specific grade. Although the Wilcox Monocarpellites resembles several of these so-called species from the Brandon lignite it can not be conclusively identified with any one of them, so that in the present unsatisfactory state of our knowledge of fossil fruits it must necessarily be considered to represent a new species.

In this connection attention should be called to the genus Hightea, which was described by 
Bowerbank ${ }^{24}$ from the abundant pyritized fruits found in the London clay of Sheppey (Ypresian). As elucidated by Bowerbank the genus Hightea possessed a one-celled valveless pericarp with large 4 to 6 angled placena and numerous down-bearing seeds, these fruits having every appearance of being five or more numerously valved capsules. Hightea is very abundant at Sheppey, and Bowerbank described no less than 10 so-called species, which are subject to the same limitations as Perkins's numerous species of Monocarpellites.

Although it is impossible to advance conclusive opinions without having studied a large suite of specimens, it seems probable that Hightea and Monocarpellites are congeneric, thus affording an important item for the correlation of these three widely separated deposits, valuable chiefly for the evidence it affords of the age of the Brandon lignite, as the parallelism between the London clay and the Wilcox is already well established.

Occurrence: Spink's clay pit, near Paris, Henry County, Tenn.

\section{Family STERCULIACEAE.}

Genus STERCULIA Linné.

Sterculia wilcoxensis Berry, n. sp.

Plate XIV, figures 1, 2; Plate.XV, figures 3, 4.

Sterculia puryearensis Berry, U. S. Geol. Survey Prof. Paper 91, pl. 72, fig. 3 (not other figures of this species), 1916.

Leaves (in discovered material) trilobate, divided from one-half to two-thirds of the distance to the base into a median conical to slightly ovate lobe and lateral, somewhat narrower conical lobes. All are acuminate, and all may be of equal length, or the median lobe may be somewhat longer. The intervening sinuses are open and rounded and of varying depth; their degree of openness depends on the attitude of the lateral lobes, for although the angle of divergence of the lateral primaries with the midrib is practically uniform, the lateral lobes and the primaries forming their midveins may be either incurved or recurved, as shown in the accompanying illustrations. The margins are entire and the texture coriaceous. Length ranging from 12 to 16 centimeters; maximum width, between the tips of the lateral lobes, ranging from 9.75 to 15.25 centimeters and

24 Bowerbank, J. S., A history of the fossil fruits and seeds of the London clay, p. 25, pls. 7-9, 1840. largely dependent on the attitude of the lobes. The petiole was evidently long and stout; it is preserved for 2 centimeters in one specimen. The midrib is stout and prominent, approximately straight or variously curved. The: lateral primaries are approximately as stout. and prominent as the midrib. They diverge from the midrib a considerable distance above the base, at angles between $35^{\circ}$ and $45^{\circ}$, and are variously curved. The secondaries are thin and not especially prominent; they are numerous, regularly spaced, and subparallel, diverge at wide angles, and are abruptly camptodrome. The tertiaries are obscure.

The present species is, on the whole, well marked. It is in many ways similar to the European Oligocene species Sterculia labrusca Unger ${ }^{25}$ and, like that and most other living and fossil species, may have varied to a fewer or greater number of lobes, although all the specimens known at present are trilobate. It may be properly considered ancestral to the Claiborne species Sterculia labruscoides Berry, a somewhat smaller form with more conical lobes and rounded base.

A fragment of this species from Puryear, Tenn., was figured in 1916 and referred to Sterculia puryearensis Berry. Recent collections from Louisiana show that this fragment represents the present species, which is quite distinct from the much larger and more ovate lobed and lobate Sterculia puryearensis. It: adds a second and striking representative of this genus to the flora of the Wilcox group, in which it is also represented by the fruits referred to the genus Sterculiocarpus.

Occurrence: Puryear, Henry County, Tenn.; collected by E. W. Berry. Goss pit, half a mile east of Mansfield, De Soto Parish, La.; collected by O. M. Ball. Carrizo sandstone half a mile west of Carrizo Springs, Dimmit County, Tex.

\section{Genus STERCULIOCARPUS Berry.}

Sterculiocarpus eocenicus Berry.

Plate XV, figure 5; Plate XVI, figure 1.

Sterculiocarpus eocenicus. Berry, U. S. Geol. Survey Prof. Paper 91, p. 288, pl. 74, figs. 1-3, 1916.

The present specimen adds considerably to our knowledge of this form. It is relatively slightly longer and narrower than the type

${ }^{25}$ Unger, Franz, Die fossile Flora von Sotzka, p. 45, pl. 28, figs. 1-11, 1850. 
and shows that the capsules were tardily loculicidally dehiscent and contained many small elongated seeds on parietal placentae. It thus differs from the other known species, namely S. sezannelloides Berry, in which the placentae were axile and the dehiscence septicidal.

Occurrence: Goss pit, half a mile east of Mansfield, De Soto Parish, La.; collected by O. M. Ball.

\section{Genus HELICTOXYLON Felix.}

Helictoxylon wilcoxianum Berry, n. sp.

Plates XVII and XVIII.

Transverse section: Vessels large, oval, very numerous and closely spaced, generally single, sometimes in oblique pairs. Rays undulating, broad, several cells wide, charged with gum. Parenchyma filling most of the space between the rays and vessels. Prosenchyma well distributed as single or double strands in the parenchyma, with greatly thickened walls.

Radial section: Vessels reticulately marked or obscurely pored. Parenchyma much septate, without discernible pitting. Prosenchyma with pointed ends, sparingly septate, with ray of very minute pores on the radial walls. Rays high, the marginal cells square, the central long and narrow. Pitting obscured by gum.

Tangential section: Vessels often with oblique scalariform perforations; walls reticulately marked. Rays fusiform elliptical, 8 or 9 cells wide medianly, 25 .to 35 cells high, the normal ray frequently continued in one or both directions by uniserial large rectangular cells. Parenchyma of short rectangular cells without discernible pitting. Prosenchyma sparingly septate, with a row of minute pores.

The wide rays, the abundance of xylem parenchyma, and the prosenchyma with simpie pits indicate that this wood represents some species of Sterculiaceae, and the size and abundance of the vessels suggest a liana. As it is not possible to make comparisons with recent material, nor desirable to propose a new generic term such as Sterculioxylon, the species is referred to the genus Helictoxylon, proposed by Felix ${ }^{26}$ for two species from the Oligocene of Antigua. Species are also known from the Tertiary of Java, Luzon, Galicia, and

${ }_{26}^{6}$ Felix, J., Fossile Hölzer Westindiens, p. 18, 1883.
Hungary. The Wilcox species appear to be entirely distinct from previously described forms.

Occurrence: Two miles east of Naborton, De Soto Parish, La.

Order THYMELEALES.

Family LAURACEAE.

Laurus verus Berry, n. sp.

Plate XVI, figures 2-7.

I am fortunate in having several specimens of this fruit preserved as a ferric oxide replacement in Wilcox sands. Several are detached from the persistent calyx with the hilum obscured, and their identity would be questionable were it not for the finding of specimens with the calyx attached which came loose from the calyx, showing the umbo. In form the fruit is a considerably prolate spheroid varying considerably in size, the minimum and maximum sizes observed being 11 millimeters in length by 7 millimeters in maximum diameter and 15 millimeters in length by 9.5 millimeters in maximum diameter. The distal end comes to a not very obvious point. The surface is smooth and polished. The calyx is small, thick, coriaceous, and gamosepalous, the sepals represented by six conical or rounded upright marginal teeth, 3.5 to 4.5 millimeters in diameter and 2.5 to 3 millimeters high. Peduncle stout and curved, 2.5 to 4 millimeters in length. These are well shown in the accompanying figures. The question of their proper generic reference may be left in abeyance for the present, as a considerable number of the genera of the Lauraceae have comparable fruits. The term Laurus is used in the present connection purely as a form genus implying their reference to this family. The only lauraceous leaves found in association with these fruits are those of Oreodaphne salinensis Berry, and even these are rare. It may be assumed that these fruits floated a considerable distance from their point of origin, as is frequently the case with modern lauraceous fruits. I am inclined to consider these fossils as representing the genus Cinnamomum, but this is entirely a matter of personal opinion.

A considerable number of fossil fruits belonging to this family have been described. Among them those from the Oligocene of Trotha and Bornstadt, in Saxony, described by Friedrich, ${ }^{27}$

${ }_{27}$ Friedrich, P., Beiträge zur Kenntniss der Tertiärflora der Provin Sachsen, pp. 128, 234, pl. 15, fig. 9; pl. 31, fig. 10, 1883. 
are exceedingly like the Louisiana fruits. Without any pretense at citing records, attention may also be called to the Cinnamomum fruits recorded by Friedrich ${ }^{28}$ from the Oligocene and those recorded by Heer ${ }^{29}$ from the Miocene of Europe.

Occurrence: Goss pit, half a mile east of Mansfield, De Soto Parish, La.; collected by O. M. Ball.

\section{Genus LAURINOXYLON Felix.}

\section{Laurinoxylon branneri Knowlton.}

Laurinoxylon branneri Knowlton, Arkansas Geol. Survey Ann. Rept. for 1889 , vol. 2, p. 256 , pl. 9 , figs. 8,9 ; pl. 10, figs. 1, 2; pl. 11, fig. 4, 1891.

Penhallow, Roy. Soc. Canada Trans., 3d ser., vol. 1, p. 98, figs. 6-8, 1908.

Berry, U. S. Geol. Survey Prof. Paper 91, p. 314, pl. 16, figs. $6-10,1916$.

This species was described in previous reports and doubtfully recorded from the Wilcox. It occurs in the Claiborne of Arkansas and Texas, according to the identifications of Knowlton and Penhallow.

A specimen from the Wilcox at Shreveport, La. (No. 207), appears to be identical with the type. It is rather indifferently preserved and adds nothing to our knowledge of the species.

Laurinoxylon wilcoxianum Berry, n. sp.

Plate XIII.

Transverse section: Vessels single or in radial pairs or triplets, rarely more, occasionally in tangential pairs or excentric. Well distributed but-sparse, no zonal arrangement or diminution in size throughout the year, oval in cross section, thin walled. Prosenchyma abundant, the walls scarcely thickened. Xylem parenchyma abundant, showing a tendency to an arrangement in tangential bands. Rays undulating, one to three cells wide, full of gum.

Radial section: Vessels full of tyloses, with pitted walls. Rays varying in height from 2 to 18 cells; marginal cells square, about twice the height and one-half the length of the central cells, their horizontal and end walls with numerous simple pits. Rays mostly full of gum. A constant feature is the large vertical series of ray cells running from one ray to another. Prosenchyma thin, fusiform; no markings or septation seen, although in speci-

${ }^{28}$ Idem, p. 215 , pl. 16 , figs. $15,16$.

${ }_{29}$ Heer, Oswald, Flora tertiaria Helvetiae, vol. 2, pl. 91, fig. 8, 1856. mens from the Claiborne group that appear to belong to this species the prosenchyma is irregularly septate. Parenchyma about twice as wide as the prosenchyma, abundantly septate; no pits seen in the Wilcox material but with numerous round pores in the Claiborne material.

Tangential section: Rays closely crowded, 2 to 3 cells wide, connected by uniserial stringers of large rectangular cells, all full of gum.

This species appears to be distinct from previously described forms. It is abundant in the Wilcox but is usually rather poorly preserved, having suffered much from decay before silicification. Much better preserved material of this species is present in the Yegua formation of Texas and will be fully described and figured in my account of the Claiborne and Jackson floras. Sections have been cut from trunks from the following localities: Haif a mile southwest (214) and 1 mile west (212) of Naborton, De Soto Parish, La.; near Dabney (242), Montgomery County, Miss.; Piney Creek (238), 10 miles east of Bolivar, Hardeman County, Tenn. All from beds of upper Wilcox age except the last, which is probably middle Wilcox.

\section{Order MYRTALES.}

\section{Family COMBRETACEAE.}

Genus TERminalia Linné.

Terminalia lesleyana (Lesquereux) Berry.

Plate XVI, figure 8.

Terminalia radobojensis Heer. Lesquereux, U. S. Geol. and Geog. Survey Terr. Ann. Rept. for 1871, Suppl., p. 15, 1872.

Magnolia lesleyana Lesquereux, Am. Philos. Soc. Trans., vol. 13, p. 421, pl. 21, figs. 1, 2, 1869; Tertiary flora, p. 248, pl. 44, figs. 1-3, 1878; U. S. Geol. and Geog. Survey Terr. Ann. Rept. for 1871, Suppl., p. 14, 1872.

Knowlton, U. S. Geol. Survey Prof. Paper 101, p. 313, pl. 82, figs. 1, 2, 1917.

Terminalia lesleyana Berry, U. S. Geol. Survey Prof. Paper 91, p. 323, pl. 89, 1916.

A large specimen of this species from Louisiana is figured in the present paper. Since my account of the Wilcox flora was published Knowlton ${ }^{30}$ has given a very excellent account of the Raton flora. In that paper the present species is transferred back to Magnolia, although no reasons are given. I have compared the fossil with a large amount of re-

${ }^{30}$ U. S. Geol. Survey Prof. Paper 101, 1918. 
cent material of both Magnolia and Terminalia and am satisfied that the fossil is much more like the latter than the former, which was Lesquereux's original identification before it became the fashion to refer all large leaves to Magnolia.

Occurrence: Goss pit, half a mile east of Mansfield, De Soto Parish, La.; collected by O. M. Ball.

\section{Order GENTIANALES.}

Family APOCYNACEAE.

\section{Genus APOCYNOPHYLLUM Unger.}

Apocynophyllum mississippiensis Berry.

Apocynophyllum mississippiensis Berry, U. S. Geol. Survey Prof. Paper 91, p. 342, pl. 108, fig. 6, 1916.

The present material contains numerous leaves of this species which average about 20 per cent larger than those previously collected, indicating a leaf about 18 centimeters in length by 4 centimeters in maximum width.

Occurrence: Goss pit, half a mile east of Mansfield, De Soto Parish, La.; collected by O. M. Ball.

Apocynophyllum constrictum Berry.

Apocynophyllum constrictum Berry, U. S. Geol. Survey Prof. Paper 91, p. 344, pl. 103, fig. 4, 1916.

This species was based on the single specimen figured, which was collected from the Wilcox of Benton, Ark. Additional material was collected recently from the clay ironstone near Somerville, Tenn. This is of importance in showing that the constricted form that suggested the name of this species was not anomalous but the normal form of this lower Eocene Apocynophyllum. It is also important in confirming the conclusion that all the known fossiliferous Wilcox in Arkansas, Louisiana, and Texas is of upper Wilcox age, and that the Wilcox sediments were progressively transgressive in the region west of the present Mississippi River.

Occurrence: Half a mile south of SomervilleWhiteville road, Fayette County, Tenn.; collected by Russell F. Ryan.

\section{POSITION UNCERTANN.}

Genus PTEROBALANUS Berry, n. gen.

The genus has the characters of the type and only known species. The name is derived from the Greek for winged fruit.

Pterobalanus texanus Berry, n. sp.

Plate XV, figures 1, 2.

Fruit of uncertain nature, either a manyseeded indehiscent capsule or a drupe with a readily flattened stone; the impression as preserved shows no trace of a stone and rather points to its having been a many-seeded capsule. The fact that the wings are so well developed rather precludes the inference that the central papillose portion of the specimen represents the base from which the essential part of the fruit had been broken away.

The remains consist of a stout stalk or peduncle, about 2.25 centimeters in length, slightly enlarged and curved proximad, expanding distad to form the margin of a central circular thickened papillose disk, which is 2 millimeters in diameter. From this margin diverge in a semicircular fashion about twelve wings or enlarged bracts. These are believed not to be segments of a calyx, because of their collective lack of symmetry, none being developed on the proximal or inner side of the central disk.

These bracts are separate lanceolate in outline, entire margined, acutely pointed, and about 5 millimeters in length by 1.5 millimeters in maximum width in their expanded median region. Each appears to have two longitudinal veins.

The systematic position of this interesting winged fruit is unknown, nor do I recall anything similar in the existing flora or in described fossil floras. It is based on the single specimen figured and its counterpart.

Occurrence: Carrizo sandstone at quarries half a mile west of Carrizo Springs, Dimmit County, Tex. 
PLATES I-XVIII. 



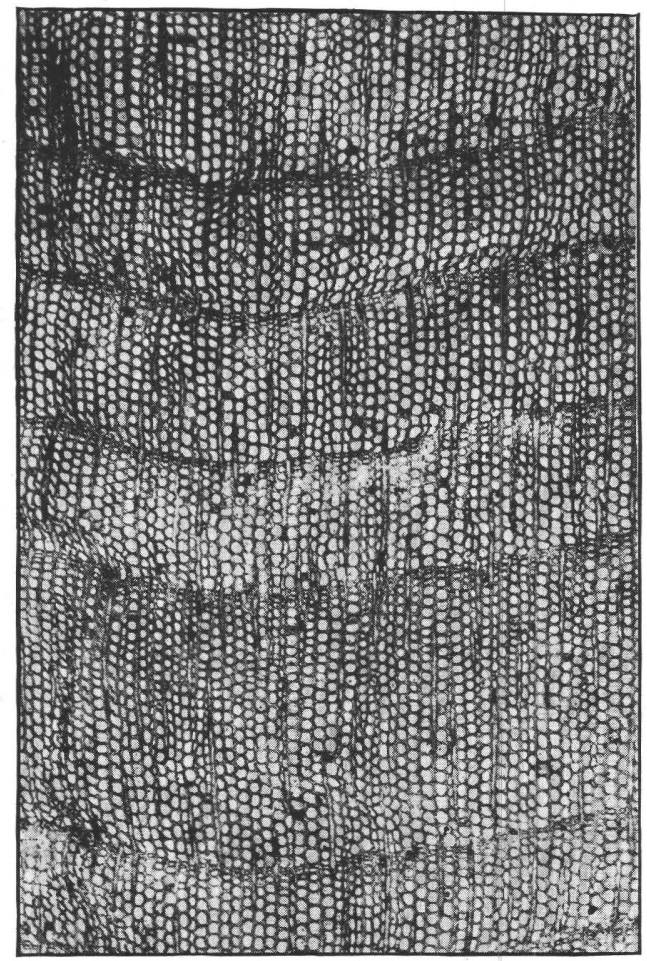

1

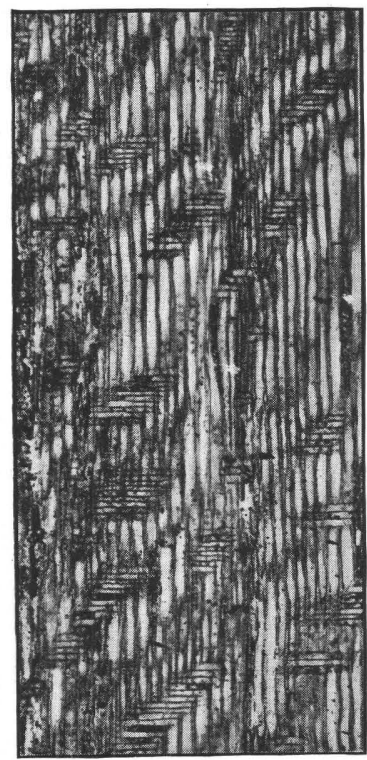

3

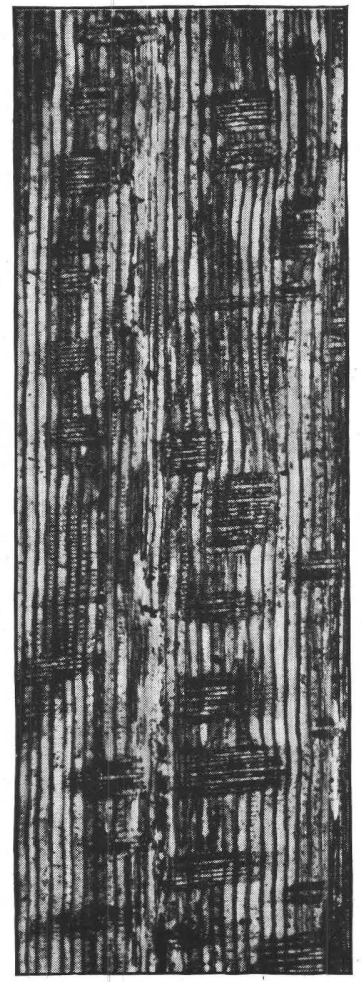

4

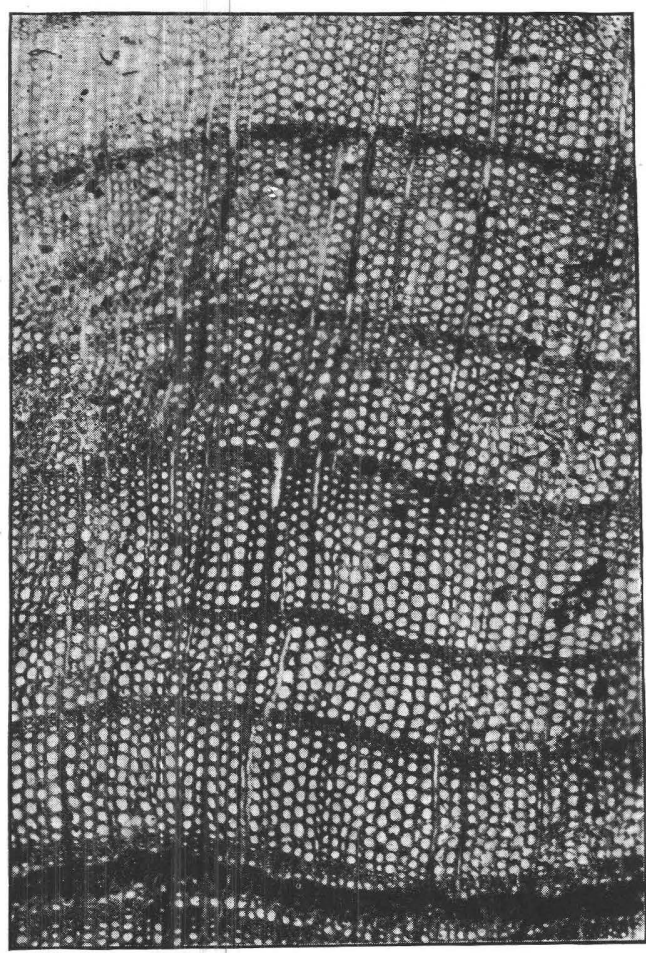

2

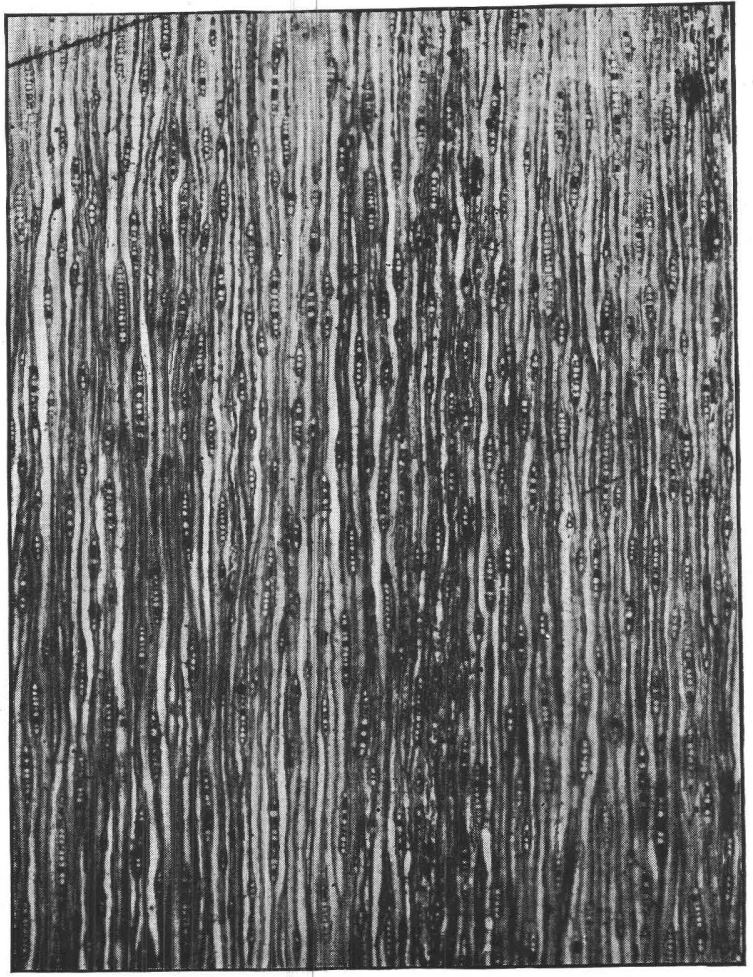

5

CUPRESSINOXYLON WILCOXENSE BERRY.

1, Transverse section showing growth rings from Shreveport, La.; 2, similar section from Caddo Lake, La.; 3 , radial seotion from Caddo Lake, La.; 4, similar section from Shreveport, La.; 5, tangential section from Caddo Lake, La. All enlarged 20 diameters. 


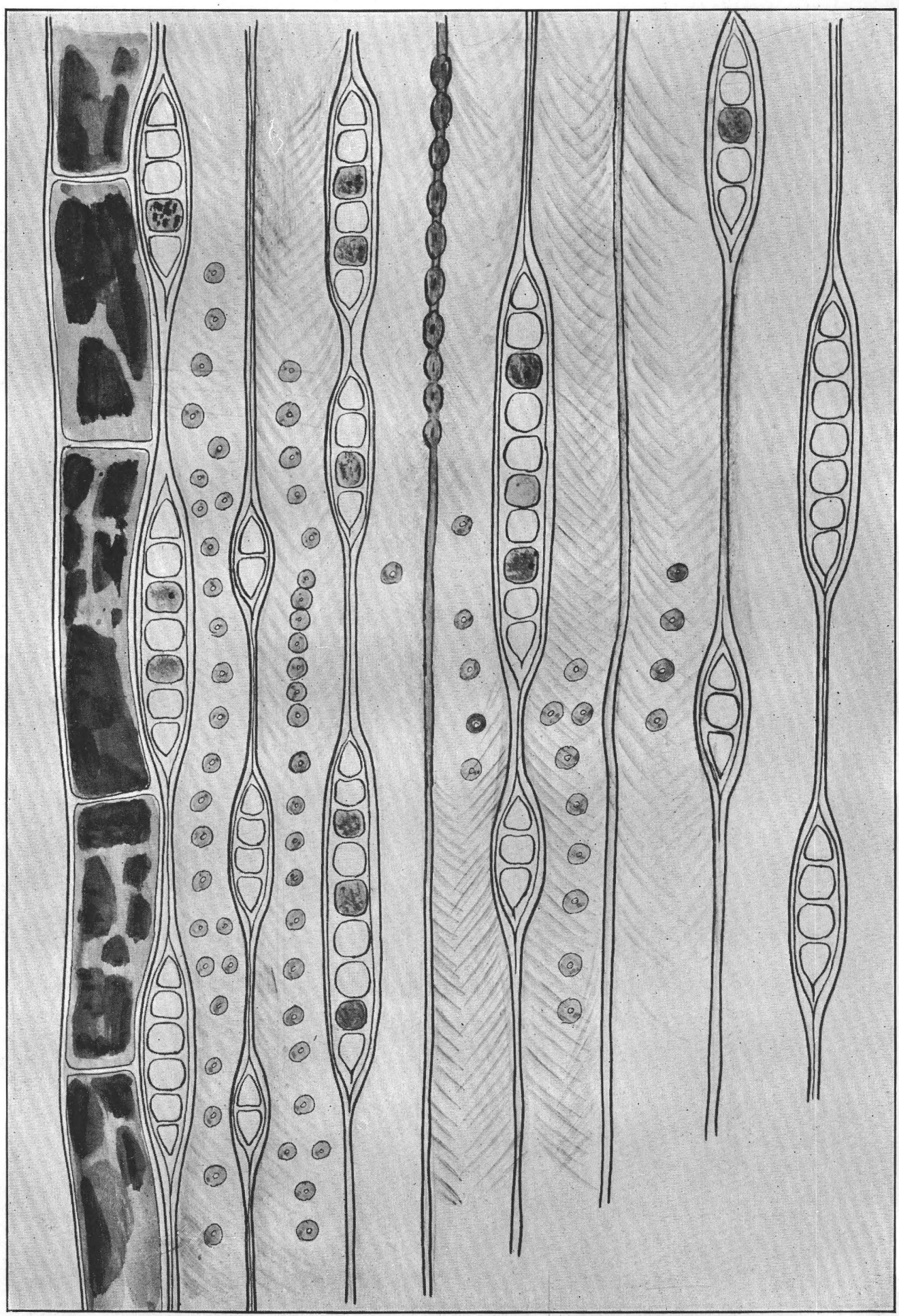

CUPRESSINOXYLON WILCOXENSE BERRY.

Tangential section from Shreveport, La., enlarged about 300 diameters. 


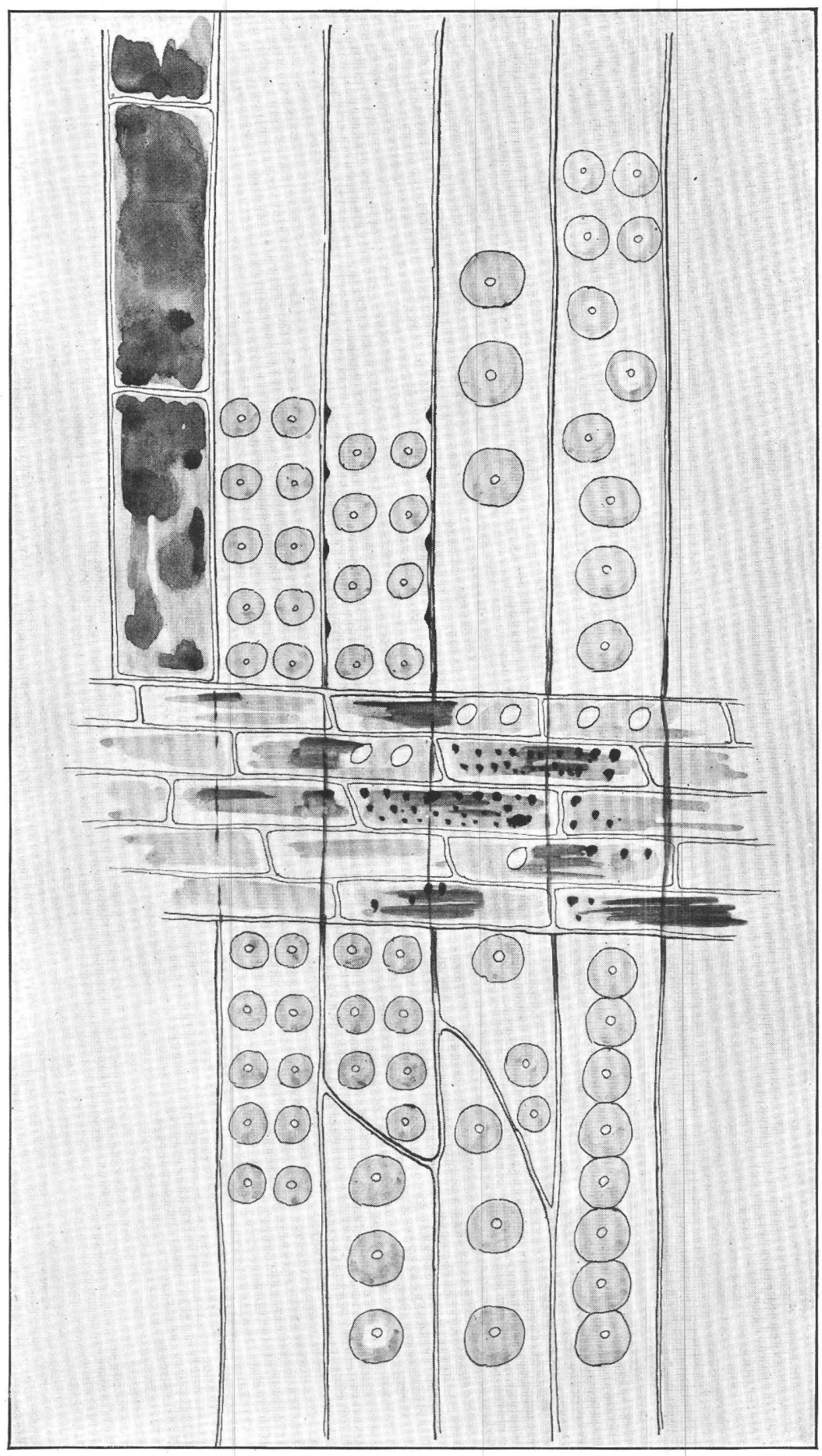

CUPRESSINOXYION WILCOXENSE BERRY.

Radial section from Shreveport, La., enlarged about 300 diameters. 


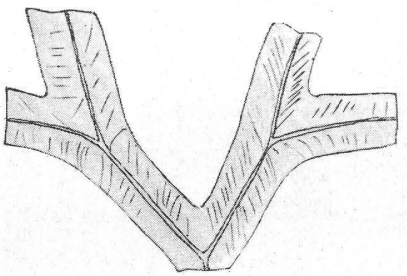

1

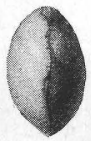

2

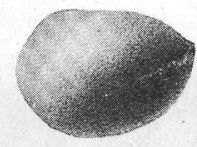

3

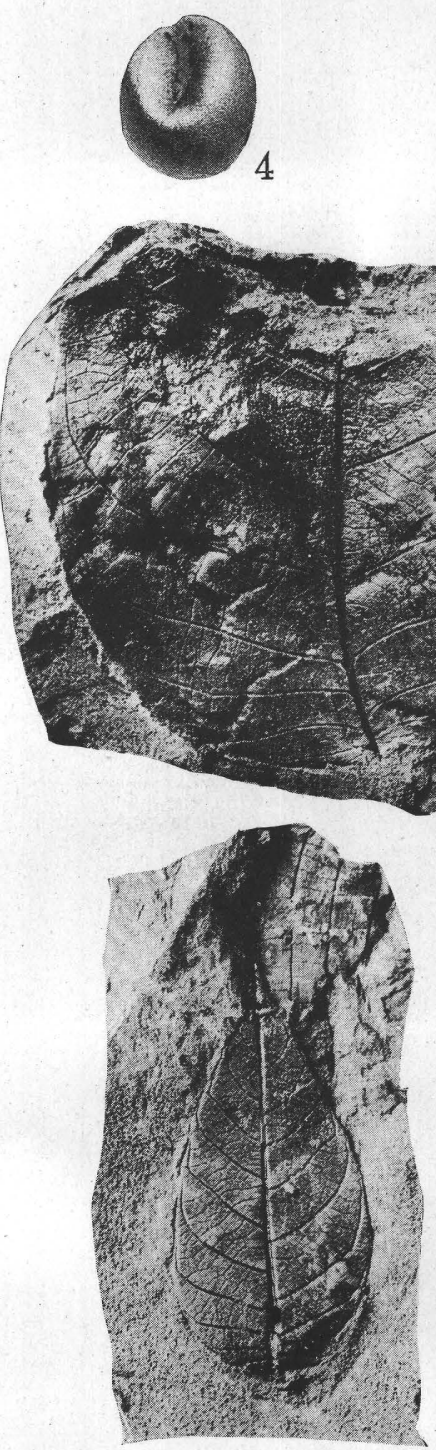

9

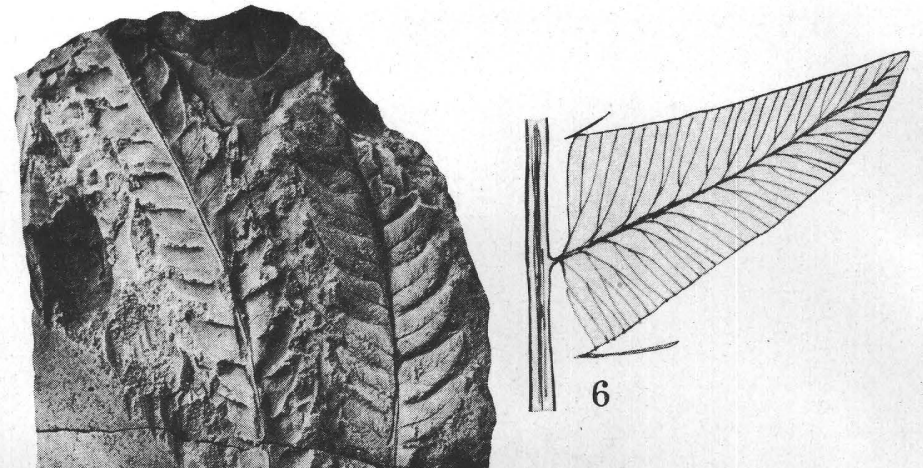

5

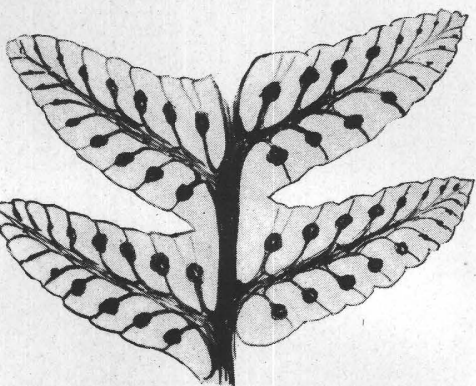

7

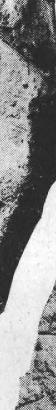

8
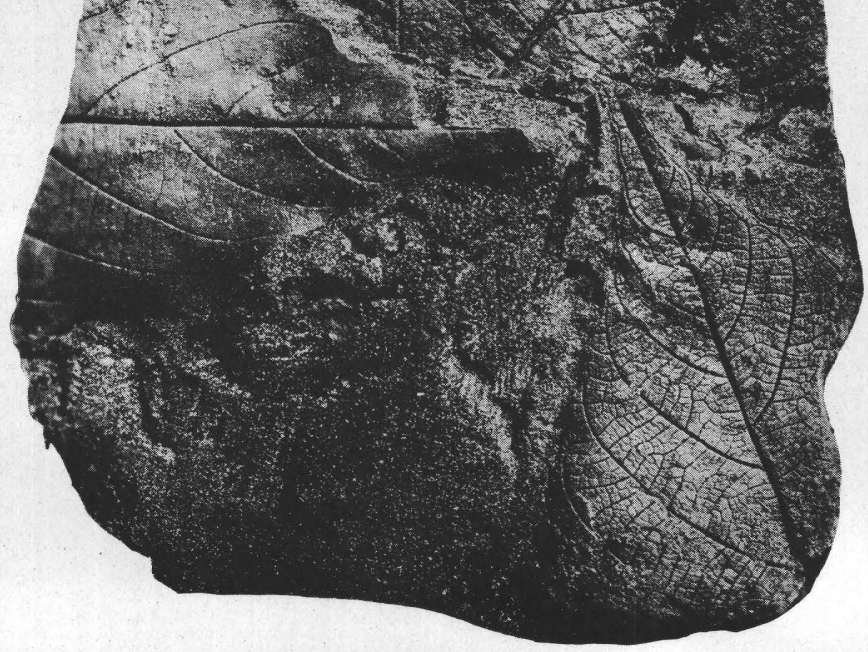

10

FOSSIL PLANTS OF THE WILCOX GROUP.

1. Marchantites stephensoni Berry, Jacksonville, Ark.; 2-4, Palmocarpon butlerensis Berry, near Oakville, Tex. 5-7, Dryopteris cladophleboides Knowlton, Goss pit, near Mansfield, La. (6, pinnule to show venation, enlarged 5
diameters; 7 , fertile pinnules, enlarged 5 diameters); $8-10$, Artocarpoides balli Berry, Goss pit, near Mansfield, La. 


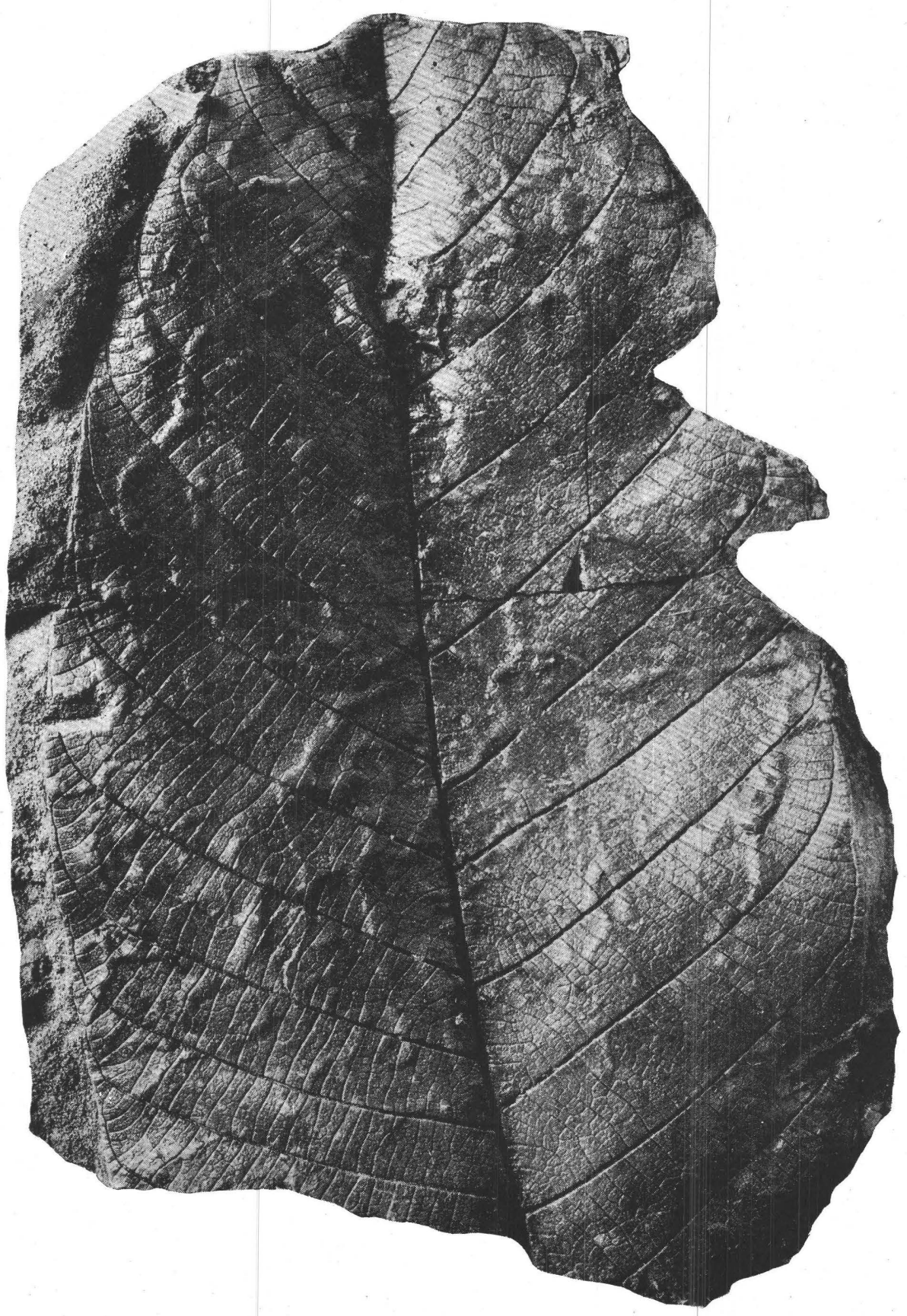

ARTOCARPOIDES BALLI BERRY.

A large leaf from Goss pit, near Mansfield, La. 

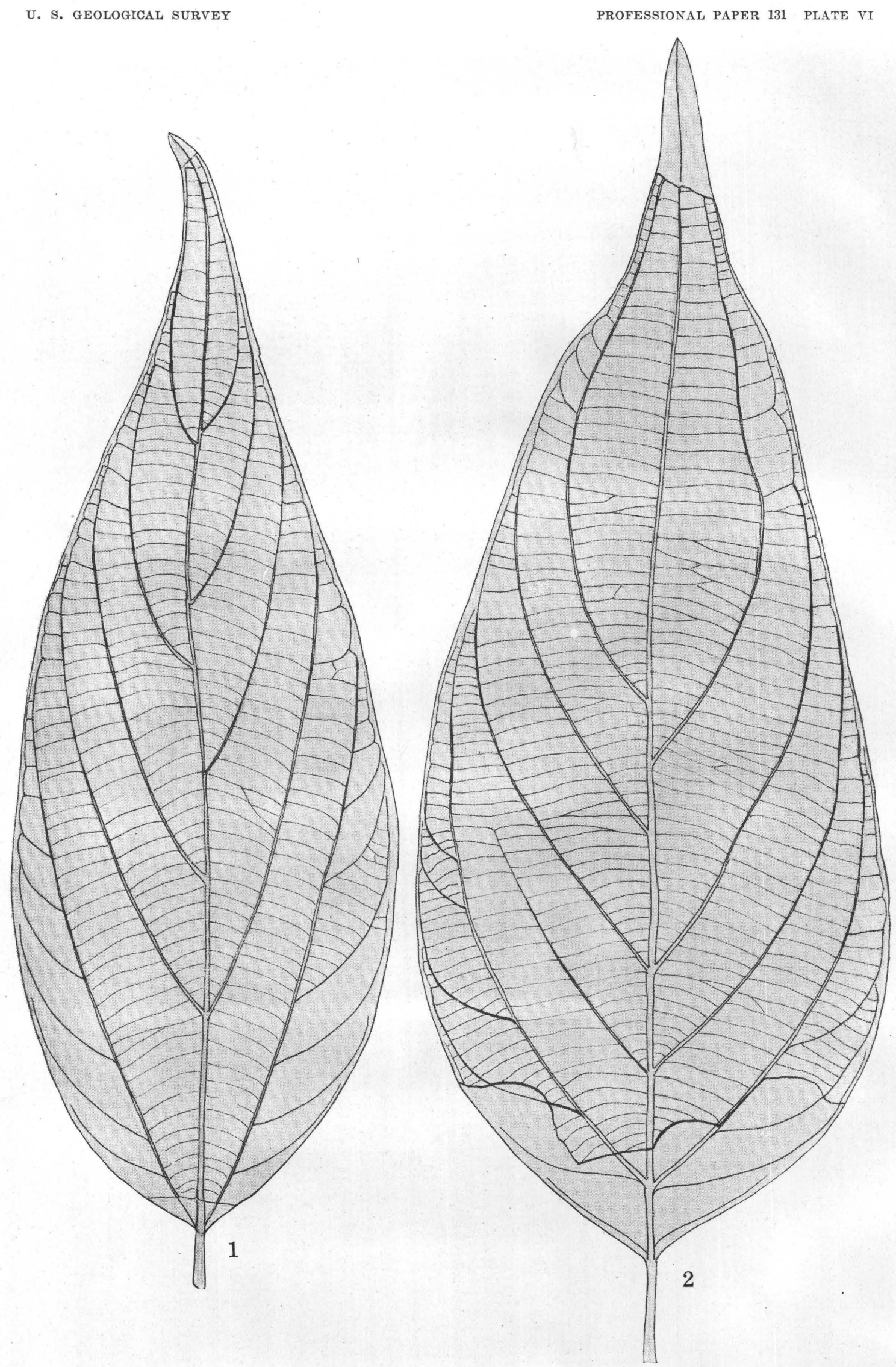

FICUS MISSISSIPPIENSIS (LESQUEREUX) BERRY.

Two of the large narrow forms from Goss pit, near Mansfield, La. 
U. S. GEOLOGICAL SURVEY

PROFESSIONAL PAPER 131 PLATE VII

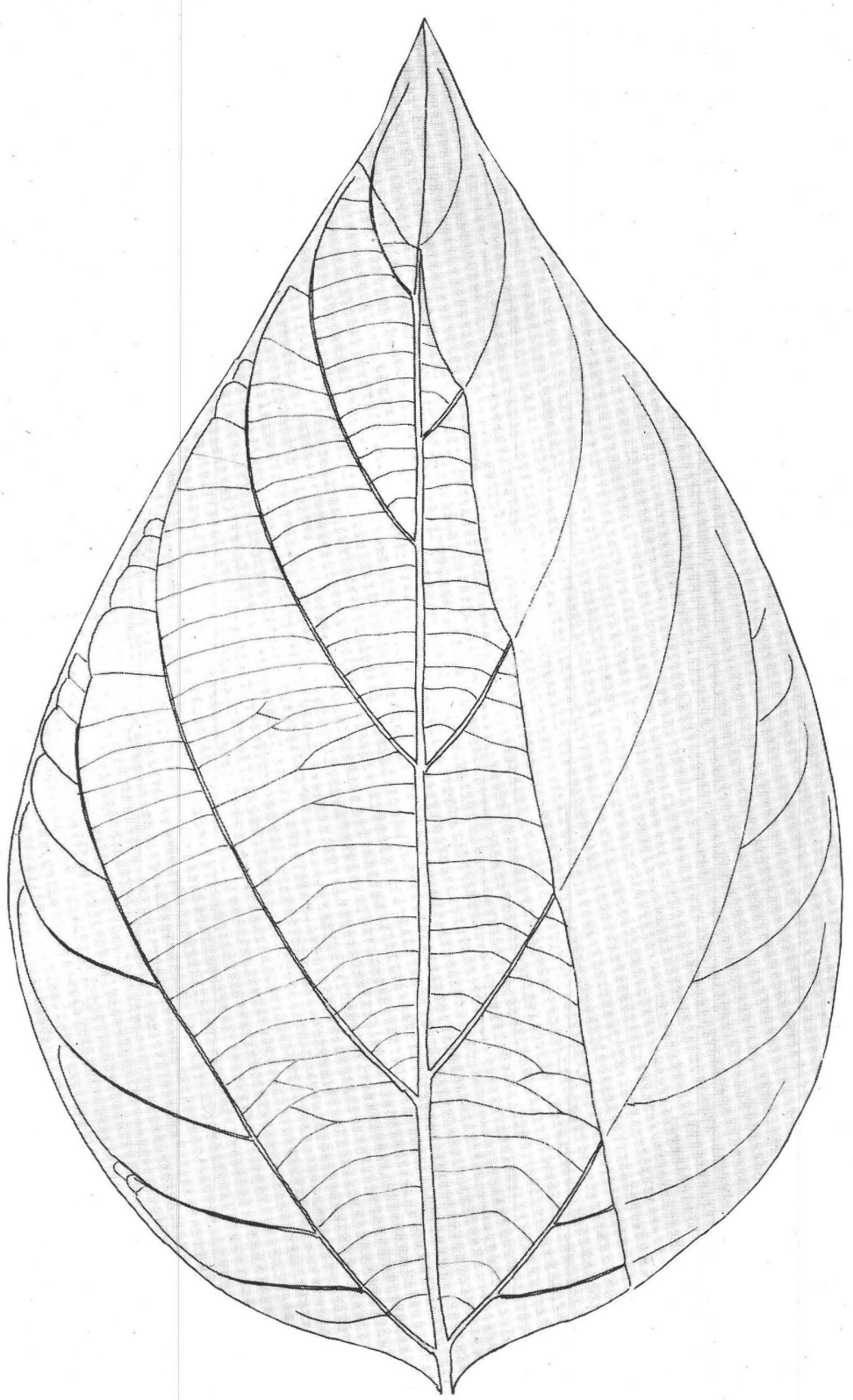

FICUS MISSISSIPPIENSIS (LESQUEREUX) BERRY.

Shorter and wider form from same locality as those figured on Plate VI. 


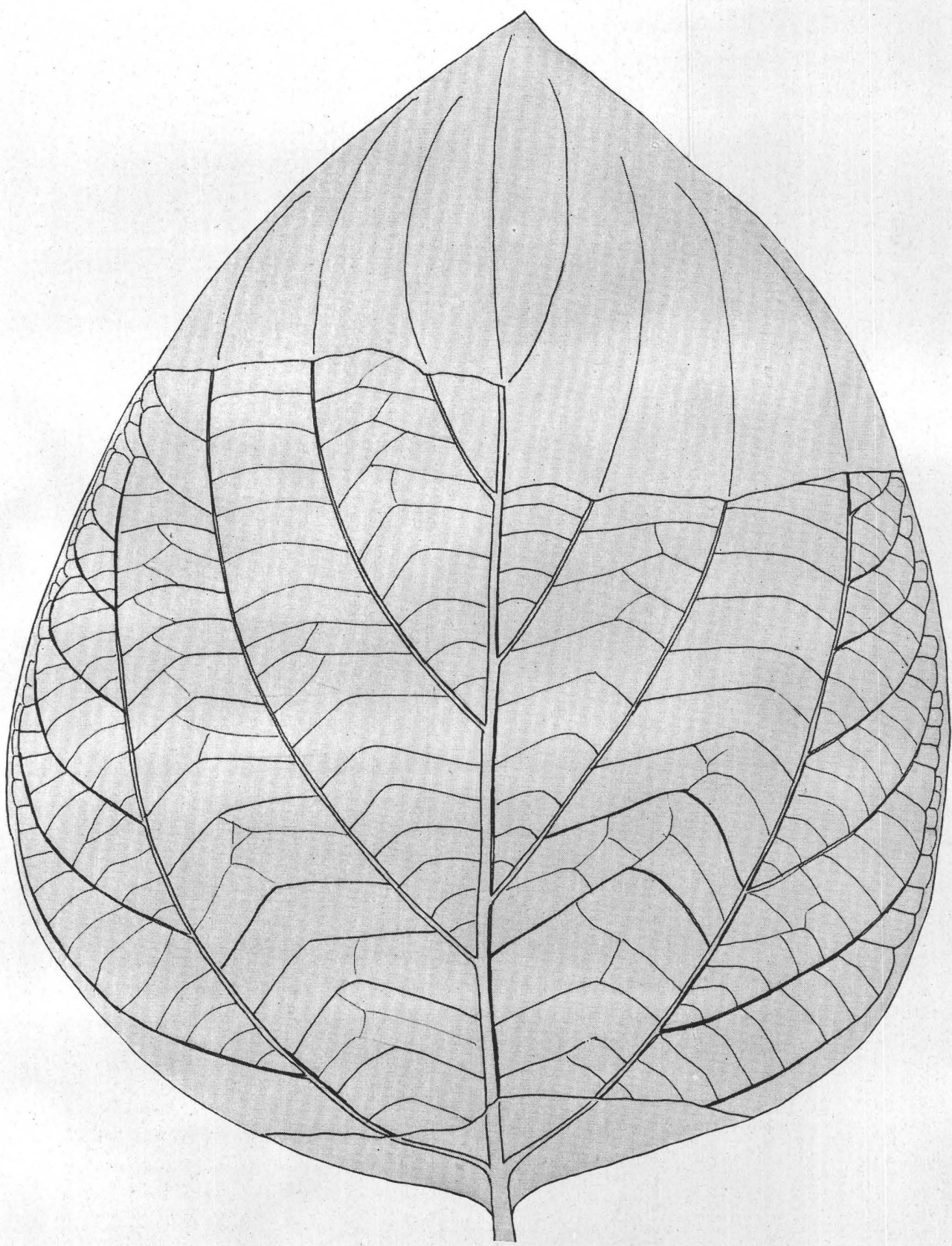

FICUS MISSISSIPPIENSIS (LESQUEREUX) BERRY.

Widest form from same locality as those figured on Plate VI. 


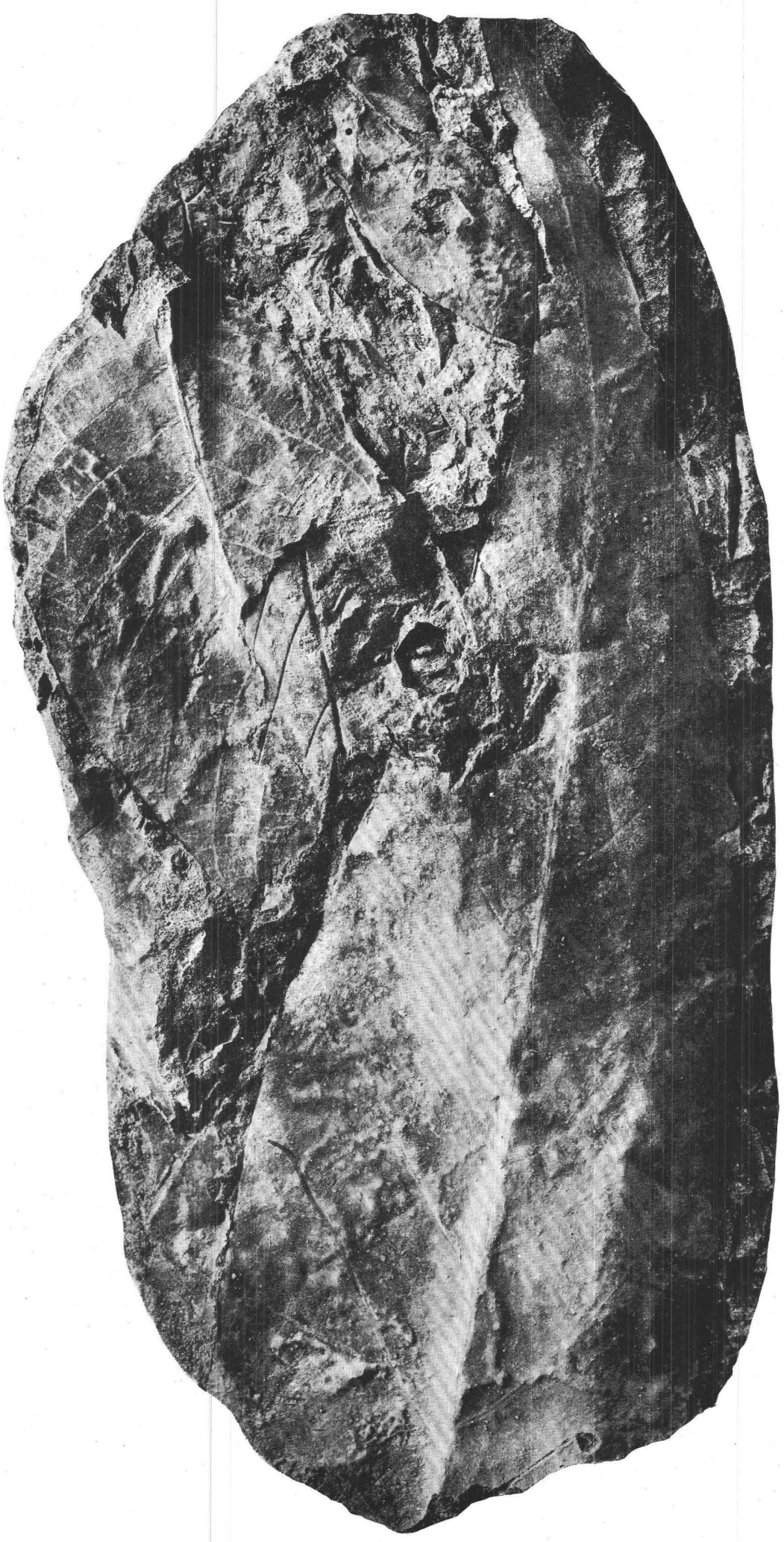

MAGNOLIA ANGUSTIFOLIA NEWBERRY.

From Goss pit, near Mansfield, La. 


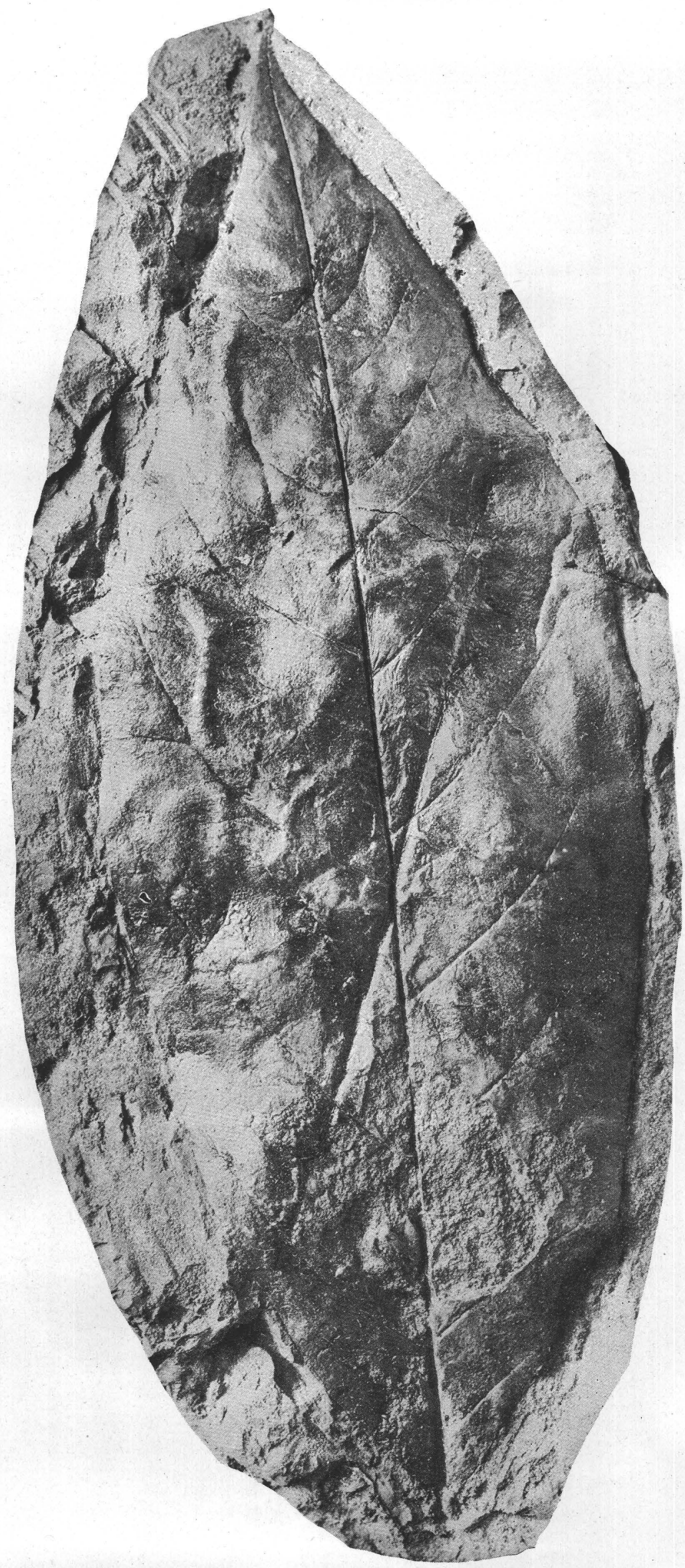

MAGNOLIA LEEI KNOWLTON.

From Goss pit, near Mansfield, La. 


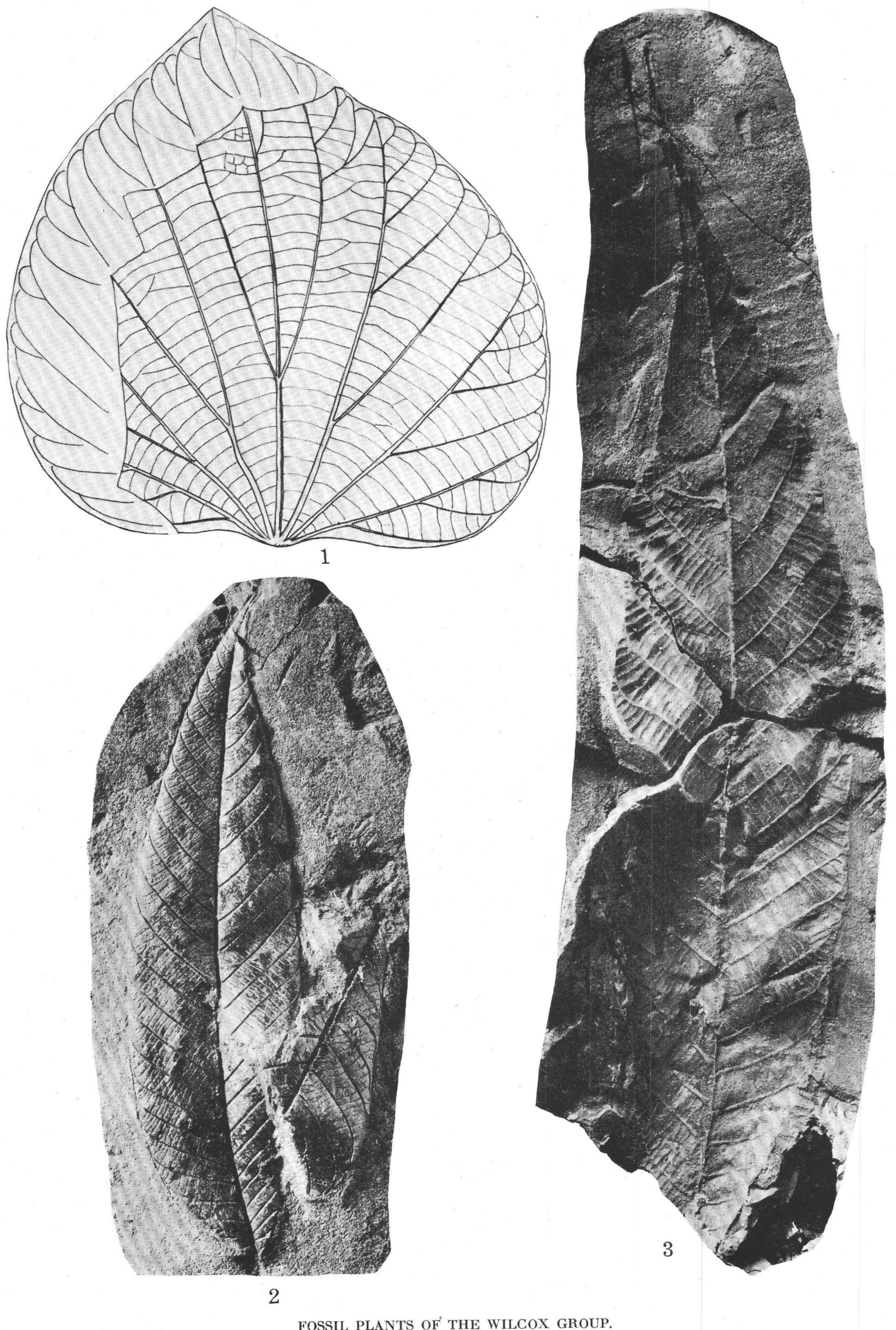
1, Menispermites cebathoides Berry; 2, 3, Rhamnus marginatus apiculatus Berry, small and large leaves. All from 


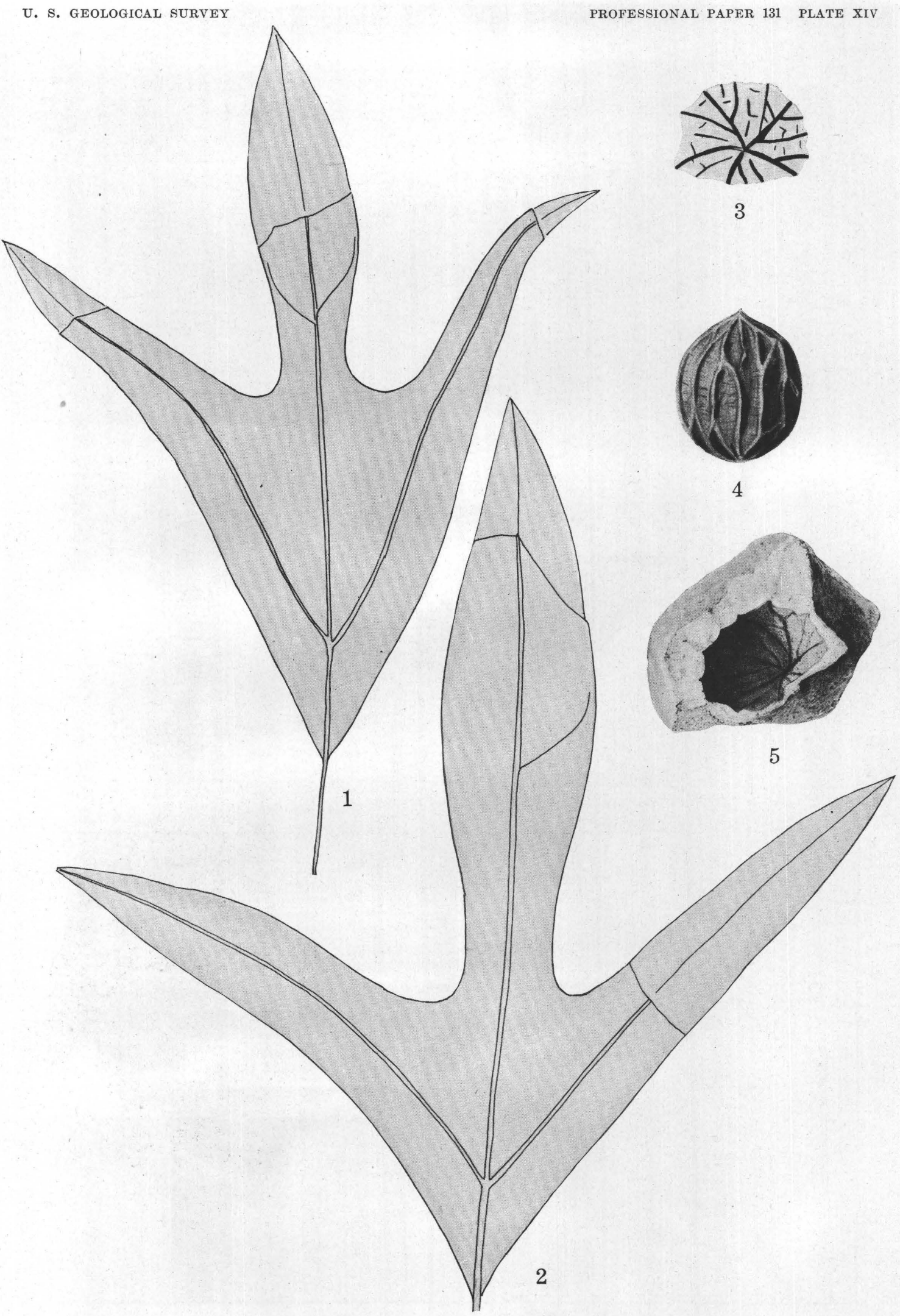

FOSSIL PLANTS OF THE WILCOX GROUP.

1, 2, Sterculia wilcoxensis Berry, from Goss pit, near Mansfield, La.; 3-5, Calatoloides eocenicum Berry, from Butler salt dome, Tex. 


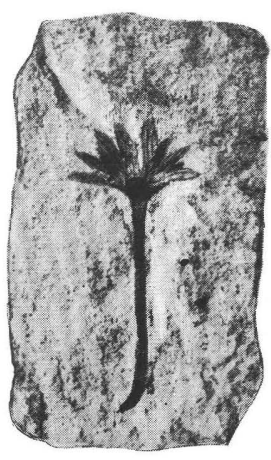

1
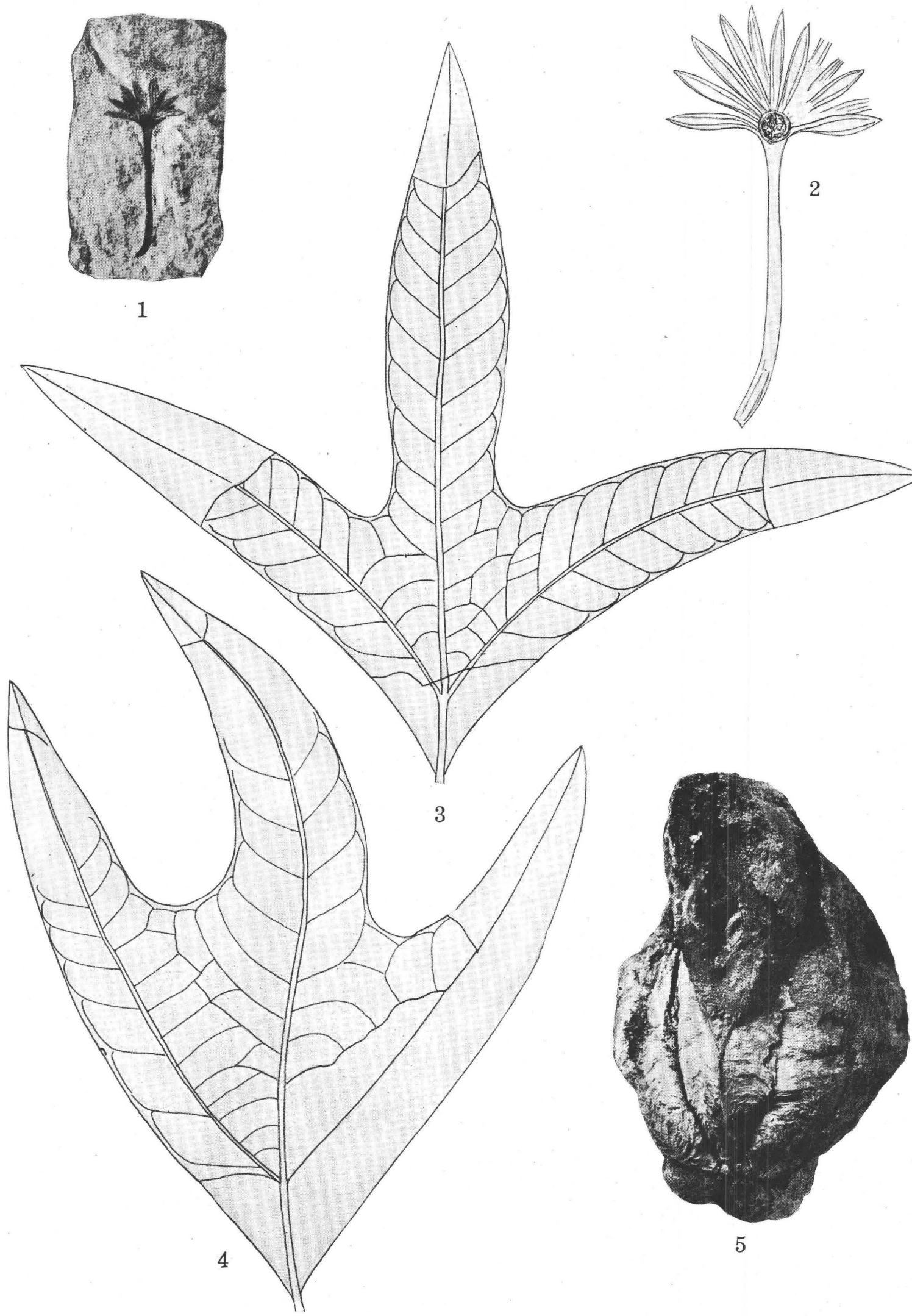

FOSSIL PLANTS OF THE WILCOX GROUP. 1-2, Pterobalanus texanus Berry; 3-4, Sterculia wilcoxensis Berry (3, Puryear, Tenn.; 4, Goss pit, near Mansfield, La.);
5, Sterculiocarpus eocenicus Berry (side view), from Goss pit, near Mansfield, La. 
U. S. GEOLOGICAL SURVEY
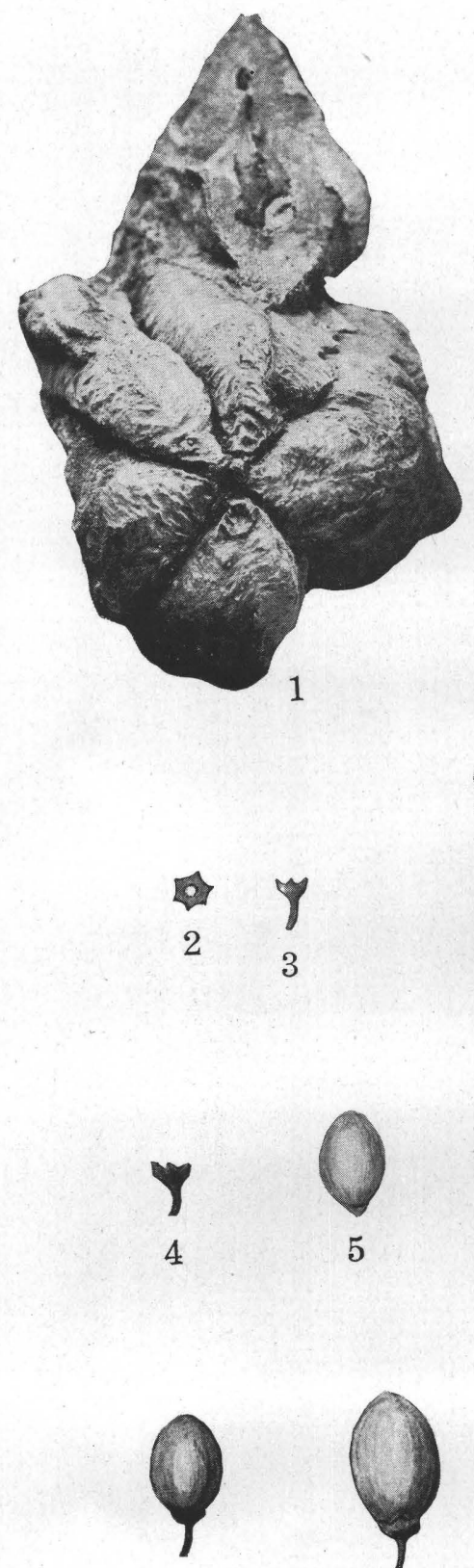

6

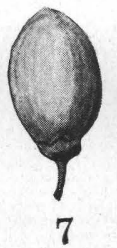

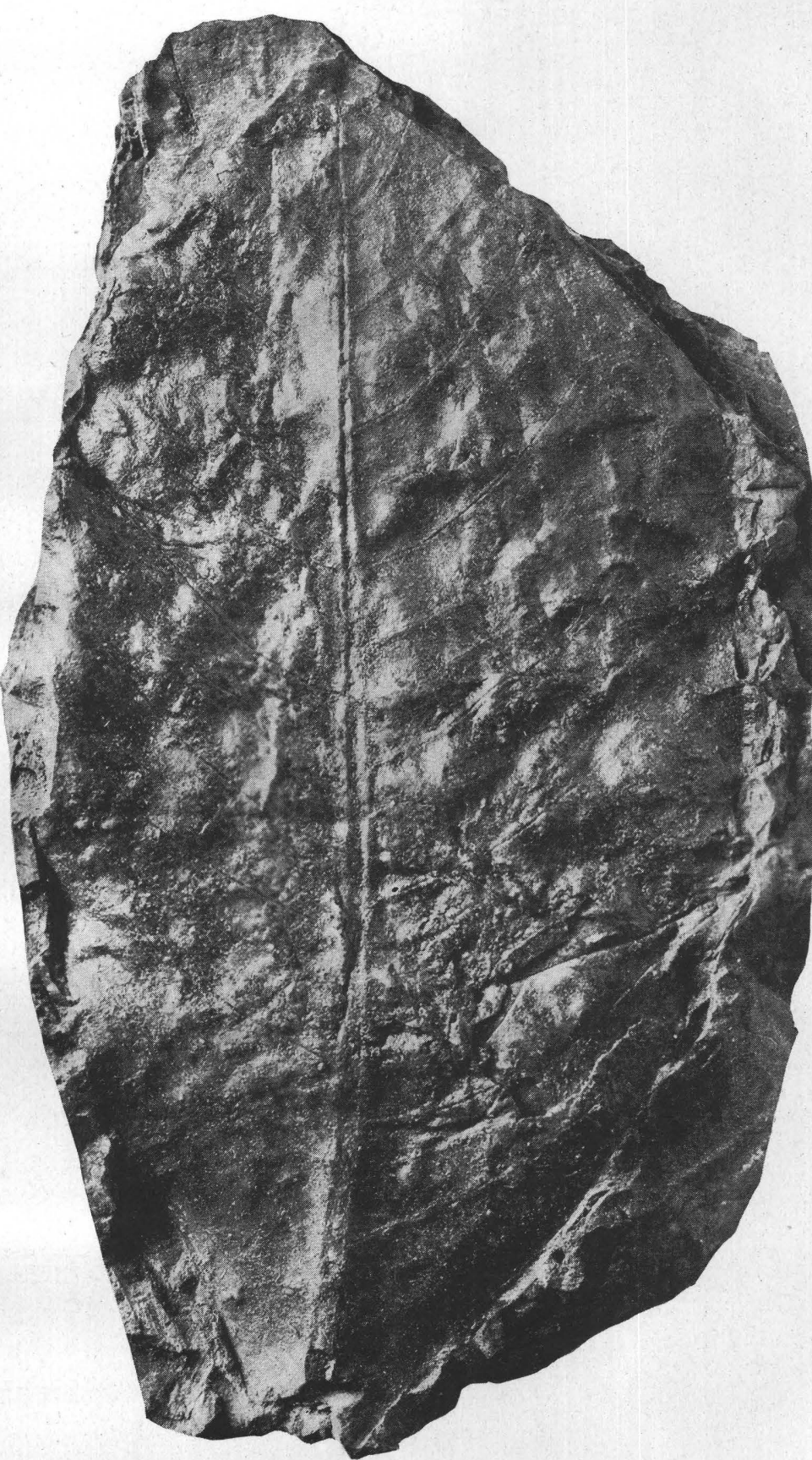

8

FOSSIL PLANTS OF THE WILCOX GROUP.

1, Sterculiocarpus eocenicus Berry (basal view); 2-7, Laurus verus Berry (2, persistent calyx from above; 3 , calyx and peduncle from side; 4 , another calyx and peduncle from side; 5 , detached fruit; 6,7 , fruits with persistent calices and peduncles); 8, Terminalia lesleyana (Lesquereux) Berry. All from Goss pit, near Mansfield, La. 


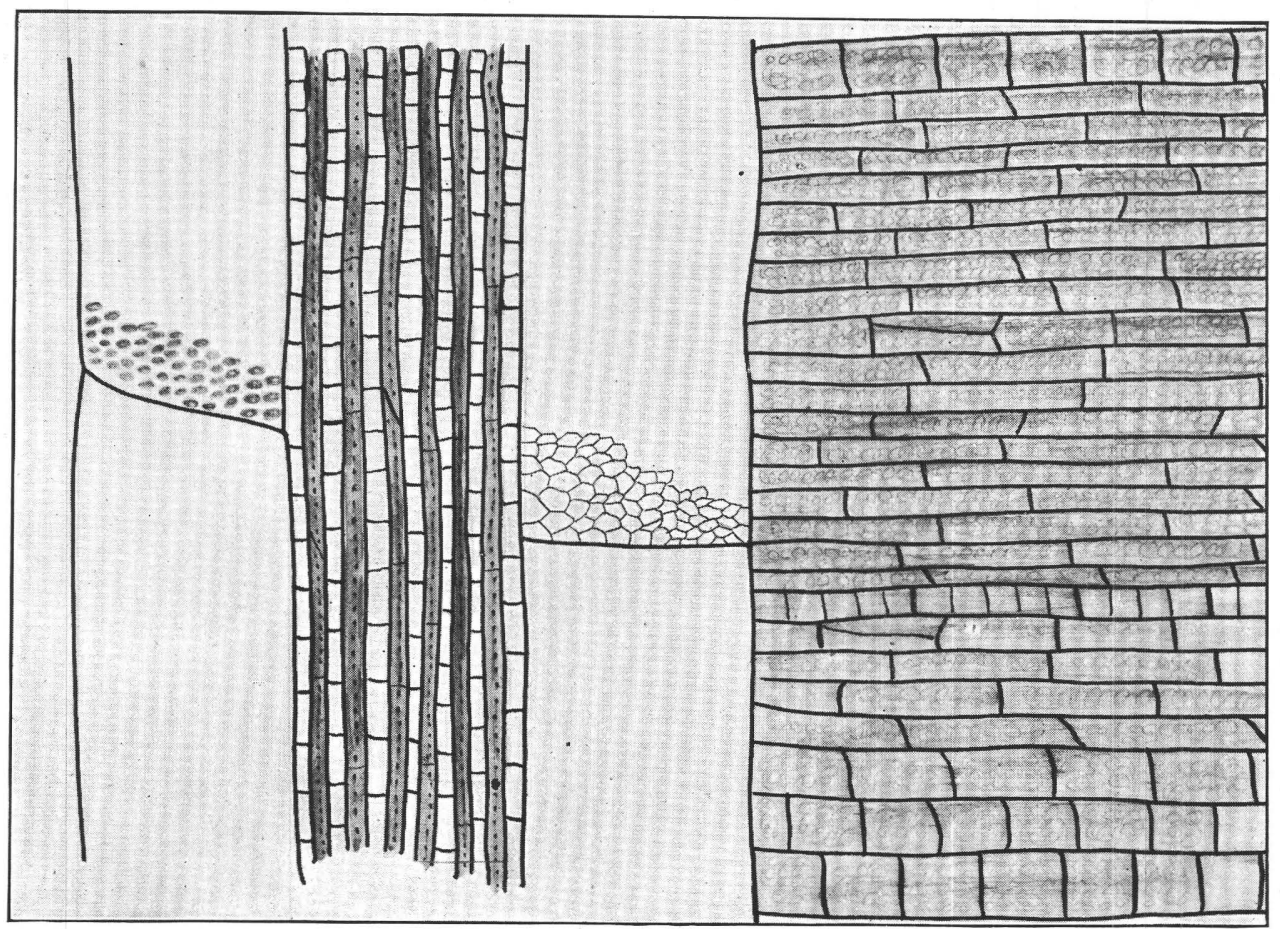

1

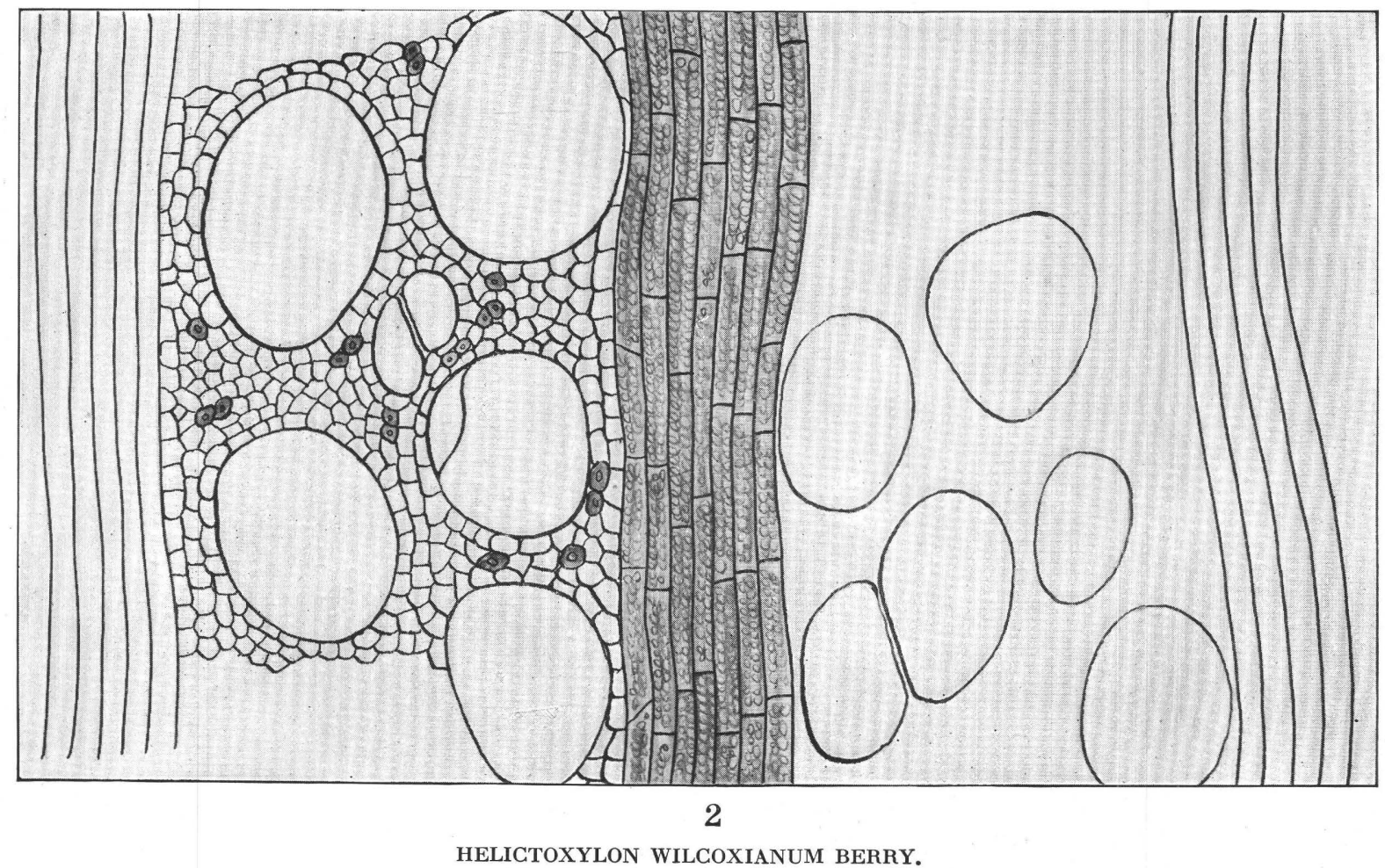

From vicinity of Naborton, La. 1, Radial section; 2, transverse section. Both enlarged about 300 diameters, 


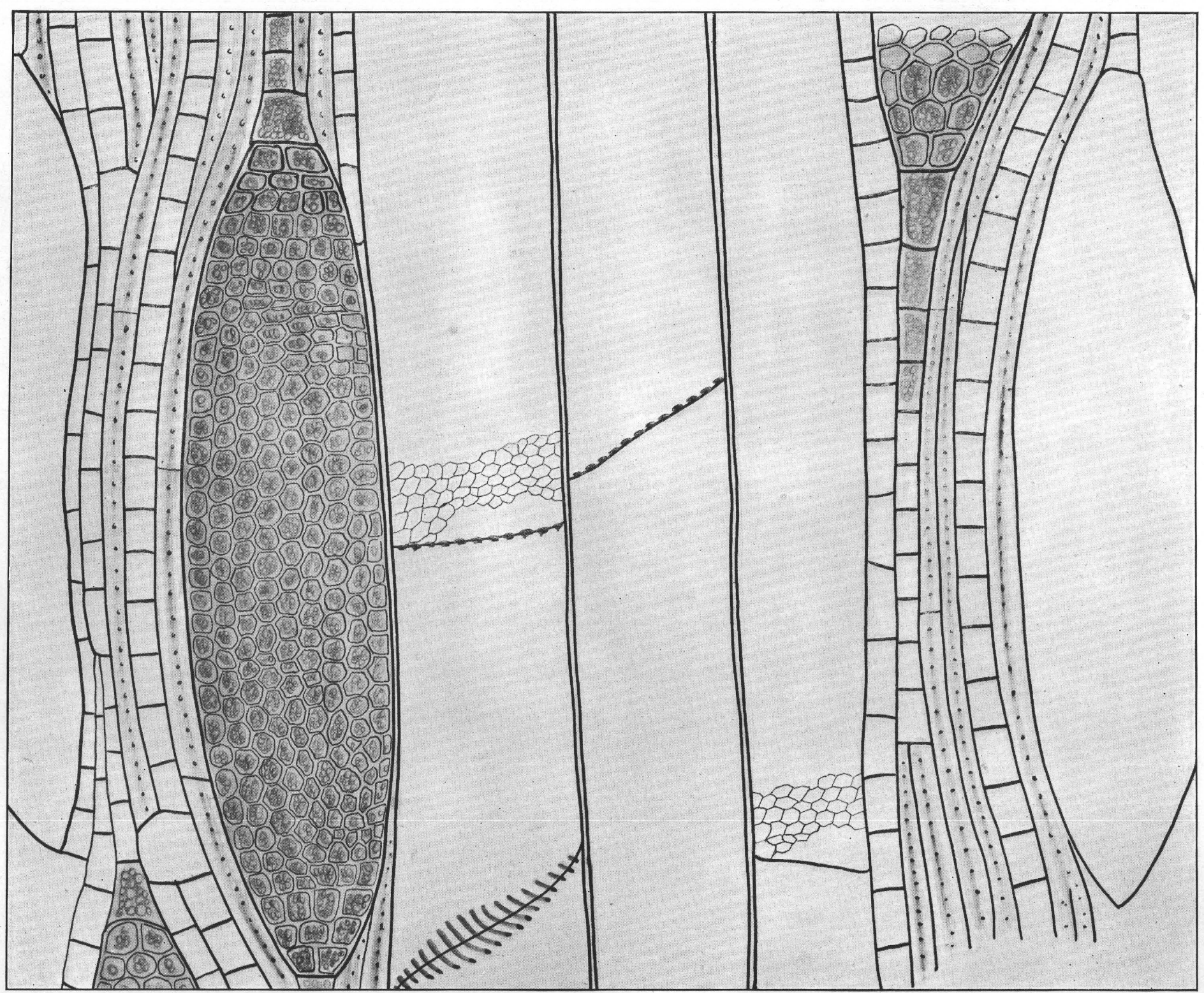

HELICTOXYLON WILCOXIANUM BERRY.

From vicinity of Naborton, La. Tangential section, enlarged about 300 diameters. 